\title{
Perspectives for an integrated understanding of tropical and temperate high-mountain lakes
}

\author{
Jordi CATALAN, ${ }^{1,2^{*}}$ John C. DONATO RONDÓN ${ }^{3}$ \\ ${ }^{1}$ Centre de Recerca Ecològica i Aplicacions Forestals, Campus de Bellaterra (UAB), edifici C, 08193 Cerdanyola del Vallès, Spain; \\ ${ }^{2}$ Centre d'Estudis Avançats de Blanes, Consejo Superior de Investigaciones Científicas, C/ d'accés a la Cala St. Francesc 14, 17930 \\ Blanes, Girona, Spain; ${ }^{3}$ Departamento de Biología, Universidad Nacional de Colombia, Ciudad Universitaria, Av. (Cra) 30 No. 45-03, \\ Bogotá, Colombia \\ *Corresponding author: j.catalan@creaf.uab.cat
}

\begin{abstract}
High mountain lakes are extreme freshwater ecosystems and excellent sentinels of current global change. They are likely among the most comparable ecosystems across the world. The largest contrast occurs between lakes in temperate and tropical areas. The main difference arises from the seasonal patterns of heat exchange and the external loadings (carbon, phosphorus, metals). The consequence is a water column structure based on temperature, in temperate lakes, and oxygen, in tropical lakes. This essential difference implies that, in tropical lakes, one can expect a more sustained productivity throughout the year; a higher nutrient internal loading based on the mineralization of external organic matter; higher nitrification-denitrification potential related to the oxyclines; and a higher metal mobilization due to the permanently reduced bottom layer. Quantifying and linking these and other biogeochemical pathways to particular groups of organisms is in the current agenda of high-mountain limnology. The intrinsic difficulties of the taxonomic study of many of the organisms inhabiting these systems can be now overcome with the use of molecular techniques. These techniques will not only provide a much less ambiguous taxonomic knowledge of the microscopic world, but also will unveil new biogeochemical pathways that are difficult to measure chemically and will solve biogeographical puzzles of the distribution of some macroscopic organism, tracing the relationship with other areas. Daily variability and vertical gradients in the tropics are the main factors of phytoplankton species turnover in tropical lakes; whereas seasonality is the main driver in temperate communities. The study of phytoplankton in high-mountain lakes only makes sense in an integrated view of the microscopic ecosystem. A large part of the plankton biomass is in heterotrophic, and mixotrophic organisms and prokaryotes compete for dissolved resources with eukaryotic autotrophs. In fact, high-mountain lake systems are excellent model ecosystems for applying an investigation linking airshed to sediments functional views. Additionally, the study of the mountain lakes districts as functional metacommunity units may reveal key differences in the distribution of organisms of limited (slow) dispersal. We propose that limnological studies at tropical and temperate high mountain lakes should adhere to a common general paradigm. In which biogeochemical processes are framed by the airshed-to-sediment continuum concept and the biogeographical processes in the functional lake district concept. The solid understanding of the fundamental limnological processes will facilitate stronger contributions to the assessment of the impacts of the on-going global change in remote areas.
\end{abstract}

Key words: Alpine lakes; global change; high-mountain limnology; palaeolimnology; Lake Cumbal; Lake Redòn.

Received: September 2015. Accepted: October 2015.

\section{INTRODUCTION}

High mountain lakes traditionally attracted scientific interest as extreme freshwater ecosystems (Löffler, 1983; Pechlaner, 1971). Nowadays, they are also the focus of research in global change as sentinel ecosystems in remote areas (Catalan et al., 2006). Long-range atmospheric transport of contaminants and climate warming are impacting these systems that were considered mostly pristine until a few decades ago (Catalan, 2015; Catalan et al., 2013a). Due to the glacial erosive action during the cold periods of the planet, many mountain ranges around the world hold lake districts: Eurasia (e.g., the Scandinavian mountains, the Alps, the Pyrenees, the Tatras, the Caucasus, the Pamirs, the Hindu Kush, Karakorum, Himalayas and other central Asiatic ranges); America (e.g., the western and eastern mountains of North America, the Andes); Africa (e.g., the Kenya, Ruwenzori, Kilimanjaro and Bale mountains) and Oceania (e.g., the Carstensz Mountains of New Guinea, and Ruapehu of New Zealand). They are probably among the most comparable ecosystems in the world, despite the climatic differences related to latitude and the uneven volcanic influence in some areas. Therefore, the study and understanding of these ecosystems contribute in a relevant way to the assessment of present and past environmental changes across the continents, in addition to its intrinsic value as aquatic ecosystems. High mountain lakes are usually embedded in areas of high natural value, what occurs in them is largely indicative of the changes in the surrounding areas and the world's wilderness.

There is not a strict definition of a high-mountain lake. 
Considering lakes that are located at high altitude is not sufficiently precise as the meaning of altitude changes with latitude (Catalan et al., 2009b). Sometimes, highmountain lakes are referred as alpine lakes, in the sense that most of them are above tree line (Catalan et al., 2009a; Eggermont et al., 2007; Vinebrooke and Leavitt, 1996; Wolfe et al., 2003). However, this is not an accurate criterion, since tree line changes through time with climate. Here, we will mostly consider lakes located in high mountains that have small watersheds and are relatively deep compared to their area. We exclude lakes of high-altitude plateaus and large valley lakes from subalpine areas, although we may occasionally make some ad hoc reference to them. We also will only marginally consider lakes directly influenced or sustained by glaciers, which due to the silty conditions constitute clearly differentiate ecosystems. Some of them may have been originated quite recently by glacier retreat (Iturrizaga, 2014).

We aim to compare the high-mountain lakes of the tropical and temperate climatic areas in the light of the currently available information, highlighting common and contrasting features. The ultimate goal is to show that a common integrated framework for the understanding of these systems is possible and necessary (Tab. 1). Most of the studies on high-mountain lakes have been performed in mountain ranges of the temperate zone of the planet; there is less information from tropical mountain lakes. At present, this bias conditions any comparison and warns about potential misconceptions. Because of the authors' respective background, examples will mostly come from the European high mountain ranges and the Colombian Andes. The data provided do not pretend to be representative, only illustrative of the contrast and commonalities between the lakes in the two areas.

\section{TOWARDS A COMMON CONCEPTUAL FRAMEWORK}

We advocate for developing a common ecological framework in which first principles could be applied equally everywhere, and only the intrinsic contingency of biogeographical and evolutionary processes should have to be considered locally or regionally. This general framework sustains in two main concepts, namely, the airshedto-sediments continuum, and the mountain lake district.

\section{The airshed-to-sediment continuum}

The concept of the airshed-to-sediment continuum provides a unifying biogeochemical framework to high-mountain lakes. Lakes are fundamentally a concavity in the landscape, and this simple topographical feature drives many of the relevant causal pathways in their functioning as ecosystems. Lake ecosystem dynamics is essentially linked to the atmospheric and watershed loadings of energy and matter (Leavitt et al., 2009). The morphological features of the concavity provide the capacity for water retention and stratification, and the physical dynamics defines an internal functional anatomy of the lake (Catalan, 1991). Airshed and watershed characteristics change through time, but, generally, at a different pace than the changes in the lake. The intermediate dynamical response of lakes permits integrating high-frequency atmospheric fluctuations and showing incipient drastic changes in the watersheds at time scales closer to those of human perception. The lake's concavity also determines the memory of the lake. The sediments play a crucial role in the lake resistance and resilience in front of occasional and cyclical perturbations. The filling of the concavity provides an ontogenic trend to the lake system, which in shallow lakes may be particularly relevant (Pelachs et al., 2011). For most high-mountain lakes, the sediments provide a record of the airshed-sediment continuum during the Holocene and Late Glacial. This record is extremely valuable to understand the past (Barker et al., 2001; Bird and Kirby, 2006; Bush et al., 2005; Catalan et al., 2009c) but also to benchmark the coming changes (Beaty and Taylor, 2009; Catalan et al., 2013b; Mcglynn et al., 2010) and improve our mechanistic understanding of the long-term dynamics of both freshwater and terrestrial ecosystems (Catalan et al., 2014).

The atmospheric forcing differs between tropical and temperature zones in seasonal and interannual patterns. Since the difference is at the top of the airshed-to-sediment continuum, even being all other thinks equal, which is not necessarily the case, high-mountain lakes will show fundamental differences between temperate and tropical zones. We aim to outline these differences in the following sections and stimulate further research and cross-links between scientific communities in both climatic areas.

\section{The mountain lake district}

High mountain lakes rarely are isolated in the landscape. They tend to appear in groups of several to many lakes forming lake districts (Catalan et al., 2009b). The functional consequences of the lake district are still scarcely investigated. The accumulation of similar ecosystems in relatively short distance should necessarily have implications for the species metapopulations dynamics and other processes related to transport among ecosystems.

How are lakes distributed in the mountains and how do they connect to lowland environments may also be of relevance. Major differences between regions may exist in this respect. Some high-altitude mountain ranges may connect with sub-Artic areas, forming a continuum for the organism metacommunities. In contrast, other temperate mountain ranges are more isolated from similar environments (e.g., African high mountains); past colonization under other climates may be more relevant than current connections (Damme and Eggermont, 2011). Tropical 
Tab. 1. Suggestions for high-mountain lake research in a unified framework based on the airshed-to-sediments continuum and functional lake district concepts.

Topic

Climate and lake dynamics

Characterization of the topological distribution of lakes and the connection with lowlands

The regional meaning of the altitudinal gradient in

limnological terms

The ecological significance of lake size and lake aspect ratio

The physical and ecological meaning of convection

Physiological and ecological consequences of major water chemistry components

Thermal and oxygen gradients dynamically structuring lake ecosystems

Phosphorus: the many faces of oligotrophy

Nitrogen cycle: from genes to ecosystems

Biogeochemistry of metals in a gradient of dissolved organic matter

UV ecology

Watershed soils and lake external loadings

Characteristic temporal scales of variability in plankton dynamics

Ecological thresholds in the distribution of the main groups of autotrophic microorganisms

Biogeographical processes

The isolation of lake districts

Climate and environmental reconstructions using sediment records

The shifting boundaries of remoteness Landscape culturization

Surveillance of current

tinct

global change

Delayed pollution from

environmental deposits

(soils, glaciers)

Development of new lakes

Climate change interactions with atmospheric contaminants

Downscaling from global to local

Upscaling from regional to global Rationale/Questions

The distribution of high-mountain lakes across the world and the relatively tractable complexity of the physical processes from the airshed to sediments make these systems excellent models for process-based investigations of how energy exchanges determine lake functioning.

Mountain lake districts are 3-D archipelagos. The degree of isolation of the islands (lakes) changes with altitude. There is a need for developing methods to characterize the topographical distribution of lakes and evaluate their ecological consequence.

The altitudinal gradient encompasses different environmental gradients. Some of them are similar throughout the planet, but others depend on regional characteristics. The way how the altitudinal continuum is segmented by vegetation also changes and has fundamental implications for mountain lakes.

Large-scale studies have shown the presence of eco-regions and ecological threshold within them. Lake morphology appears as a main driver of lake ecosystem organization with important implications for species distribution.

Convection is one of the physical processes harder to characterize and understand. Mixing in most large lakes of the world is mostly wind-driven. However, in high-mountain lakes convective mixing is critical. Therefore, they offer an excellent model for developing studies in the fundamental of the physics and also in the ecological consequences. High-mountain lakes offer a full range of different dominant cations and singular anion compositions. Statistical approaches indicate that this is a key factor for many species of organisms. However, the fundamental physiological and ecological causes for that are only superficially understood.

The contrasting seasonal patterns of temperature and oxygen across mountain lakes are excellent benchmark for a dynamical understanding of succession in the microbial communities.

High-mountain lakes are mostly oligotrophic, yet they show thick anoxic bottom layers (pseudo-eutrophy). The phosphorus cycling within these contrasting conditions might provide new findings in biogeochemistry and microbial ecology.

The nitrogen cycle occurs upon a broad redox range. High-mountains provide contrasting redox gradients between temperature and tropical areas, which may be useful for unveiling the coupling of the $\mathrm{N}$ biogeochemical cycle and the ecology of microbial groups driving it.

The harsh high-mountain conditions offer fresh bedrocks that may provide spots of lakes with high metal content. These may or not coincide with high organic matter loads. This diversity of metal-organic matter environments is an opportunity for new findings in metal biogeochemistry and related microbiological processes.

High UV radiation is a distinctive trait of high-mountain lakes. There is still a wealth to discover about photochemical processes and biological influences of this situation. Comparison between tropical and temperate lakes may provide some new clues.

Many biogeochemical properties of high-mountain lakes correlate with the degree of soil development in their watersheds. Temperate and tropical areas provide contrasting settings that may offer new clues for process understanding.

In tropical lakes, the water column gradient may encompass more variation in the planktonic communities than the seasonal changes. This main difference with temperate lakes indicates that the characteristic scales of environmental and community changes differ markedly, with unknown consequences yet.

The composition of autotrophic microorganism differs markedly across high-mountain lakes. The changes are not smooth but seem to respond to ecological thresholds that determine sudden changes. Defining these thresholds and unveiling the causes behind are an interesting topic for research.

High-mountain lakes can be seen as islands that have been colonized recently. Therefore, they are suitable for studies on colonization $v s$ competition effects, microevolutionary dynamics, and other biogeographical processes that the particular spatial and historical setting offers.

Mountain lake districts are islands of islands. How the nature of lowlands surrounding the mountain lake districts affects their communities, which is the connectivity with similar systems located far away are topics worth to investigate taking advantage of the contrasting situations across continents.

High-mountain lakes are excellent settings for paleolimnological reconstructions of the Holocene and Lateglacial environmental changes. In particular, they can offer calibration sets and process understanding that are not always similarly available in other systems.

Remoteness is a convenient operational definition for the boundary in the landscape between local and non-local human influence. This limit has been historically shifting and will do so under current climatic and social changing conditions.

Relatively cheap instrumentation of high-mountain lakes and their watershed may provide regional records of dis-

aspects of current global change.

For decades, atmospherically transported pollutants have accumulated in natural deposits, with climate change, they are remobilized. What are the consequences?

The present glacial retreat is causing the appearance of new lakes in many mountain ranges. The study of these systems may help in a better understanding of the lake ontogeny and initial colonization and system changes during early Holocene and Lateglacial changes.

After sulfur emission reduction, many acidified systems are chemically recovering. Will climate warming accelerate biological recovering? Will these ecosystems face new challenges? On the other hand, what may happen in areas of massive new extensive agricultural or industrial development?

Understanding and mapping the regional impacts of atmospheric changes deserves dedication and networking in international initiatives. The research performed at high-mountain lake sites requires upscal
in a coherent way that could contribute to evaluating the state of the biosphere globally. 
areas also show a high diversity of situations. Some areas may limit with arid lands, poor in aquatic systems or, if present, of quite different conditions. Contrastingly, other areas may form a continuum with regions extremely rich in aquatic systems and hot spots of biodiversity (e.g., tropical Andes; Hoorn et al., 2010). In the cases in which a continuum of aquatic systems exists, from mountaintops to lowlands, is interesting to investigate, among different groups of organisms, the correspondence of their respective altitudinal distributions. In summary, both temperate and tropical high-mountain lakes are excellent settings for studies on biogeography and short-term evolutionary dynamics (Ventura et al., 2014).

The lower limit of high-mountain lake districts tend to be located at higher altitude in the tropical zones ( $>3000 \mathrm{~m}$ asl) than in temperate areas, due to the predominant glacial origin of the lakes. Therefore, tropical high mountain lakes districts tend to present lower density of lakes and a higher isolation between lake patches than in the large mountain ranges of the temperate zone (Lewis, 1996). Mountain range mean elevation and the orientation of the slopes may introduce additional regional differences. The ecological implications (e.g., metacommunity dynamics) of the topological distribution of lakes merit further general investigation worldwide.

The altitudinal gradient has some features that repeat similarly throughout the planet and others with a regional character; for instance, precipitation does not always change in the same way with altitude (Körner, 2007). Therefore, the environmental meaning of altitude has to be defined regionally, and comparison between regions has to be made according to ecologically meaningful benchmarks. In the European high mountain lakes, the duration of the winter ice cover have been used to compare altitudes among mountain ranges located at different latitudes (Catalan et al., 2009b). For instance, $2700 \mathrm{~m}$ asl in the Pyrenees (latitude $42-43^{\circ} \mathrm{N}$ ) correspond to about 2000 $\mathrm{m}$ in the Tatra Mountains ( $49^{\circ} \mathrm{N}$ and more continental). Another reference for relative altitude can be the treeline, which responds to similar environmental conditions throughout the globe unless water is limiting, or human deforestation had lowered it (Paulsen and Korner, 2014). Some groups of aquatic organisms may show distributional discontinuities coinciding with vegetation belts (De Mendoza et al., 2015; Eggermont and Verschuren, 2007). All in all, the changing multivariate nature of the altitudinal gradient has to be taken into account; some variables may be comparable across areas but others not.

\section{LAKE MORPHOLOGY}

The average aspect ratio (length $v s$ depth) of lakes resulting of the eroding action of glaciers depends on the steepness of the landscape. Sub-Arctic lakes are larger than alpine lakes of similar depths (Fig. 1). Tropical lakes of glacial origin are morphologically closer to sub-Artic lakes than alpine lakes (Fig. 1), perhaps, because they occur at higher altitude in more open landscapes. Nonetheless, studies have focused in relatively large lakes and the myriad of small lakes existing in some regions have largely being ignored. A less biased survey would likely provide a distribution with more elements similar to temperate high-mountain lakes. On the other hand, lakes with other origin are more common in tropical areas than in temperate ones. Lakes of volcanic origin may predominate over large tropical areas in different continents. Tectonic and karstic lakes tend to appear at lower altitudes than most of the high-mountain lakes in the region and, probably, they merit a particular consideration within any evaluation of the mountain lake district.

The aspect ratio is relevant because depth provides stability, whereas length facilitates wind action (Imberger, 1985). Thus in lakes of low aspect ratio weaker density gradients can maintain stratification against wind. In general, high-mountain lakes tend to show low aspect ratio (Fig. 1). However, according to existing data, tropical high-mountain lakes will be morphologically closer to Sub-Arctic lakes than temperate alpine lakes. This similarity adds to other, such as allochthonous organic carbon loadings. The main difference between the two systems is the range of actual temperatures.

\section{WATER CHEMISTRY}

\section{Major components}

Most high-mountain lakes are located in basins of crystalline rocks of slow chemical weathering. As a consequence, their waters show low total salt content (i.e., conductivity $<100 \mu \mathrm{S} \mathrm{cm}$ ), relatively low acid neutralizing capacity ( $\mathrm{ANC}<500 \mu \mathrm{eq} \mathrm{L} \mathrm{L}^{-1}$ ), and circumneutral $\mathrm{pH}$. In general, there is a close correspondence between the rock basin substrate and the water main solutes, particularly, concerning cations (Camarero et al., 2009b; Catalan et al., 1993; Psenner and Catalan, 1994). Departure from this general feature may be due to the presence of minority but highly reactive bedrocks in the watershed (e.g., carbonate or sulfide-rich rocks) or to the strong influence of marine sea salts (Fig. 2) (Camarero et al., 2009b). Therefore, differences in major elements between tropical and temperate high-mountain lakes result from the predominance of one substrate or another in a certain region. Calcium is usually the dominant cation, however, in areas with strong volcanic influence or unusual bedrocks (e.g., gypsum) other cations may become dominant (e.g., $\mathrm{Mg}$, $\mathrm{Na}$ ). In many tropical areas, the volcanic influence is common (Donato-Rondón , 2010) and, consequently, water composition differs from the most usual in the temperate zones; magnesium or sodium predominates over calcium (Fig. 2) (Degefu et al., 2014). Water composition is an im- 
portant factor for the distribution of many organisms (Kernan et al., 2009), particularly for osmotrophs (DonatoRondón, 2010).

Anions usually comprise more diverse sources than cations. The capture of atmospheric $\mathrm{CO}_{2}$ during rock weathering provides bicarbonate, marine atmospheric deposition brings chloride and sulfate, although the main source of the latter is usually rock weathering (Camarero et al., 2009b). Locally, particularly in volcanic bedrocks, unusual anions (e.g. fluoride) can achieve concentrations above water quality standards (Degefu and Schagerl, 2015a). During the industrialization burst, sulfur and nitrogen oxides were emitted to the atmosphere without much control, causing the acidification of remote sites, including many mountain lakes (Curtis et al., 2005). Control of emissions, particularly sulfur, have resulted in the recovery of some strongly impacted areas (Kopáček et al., 1998). However, nitrogen deposition in the form of nitrate and ammonium is still high in many high mountain areas of the world and may be increasing with intensive agriculture, industrialization and urbanization in other loca- tions. Little information is available on nitrogen deposition in tropical high-mountain areas and the effects that may cause (Matson et al., 1999). In general, the atmospheric loading on a particular site depends on the lake geographical position respect the emission areas and the air mass circulation (Camarero and Catalan, 1996). Recursive fire episodes in lowland tropical areas may drive some element inputs at high altitude (Peters et al., 2013).

In pre-industrial time, atmospheric nitrate deposition was low. However, estimations based on human population and agricultural and livestock practice indicate that could have been relevant in affecting the nitrogen cycle much earlier than previously thought (Kopáček and Posch, 2011).

\section{Dissolved inorganic carbon}

In temperate zones, organic carbon loads from the watershed vegetation and soils are usually low, and lake water shows low dissolved organic carbon (DOC usually $<1 \mu \mathrm{g}$ $\mathrm{C} \mathrm{L}^{-1}$ ). Only when relatively low mountains merge with

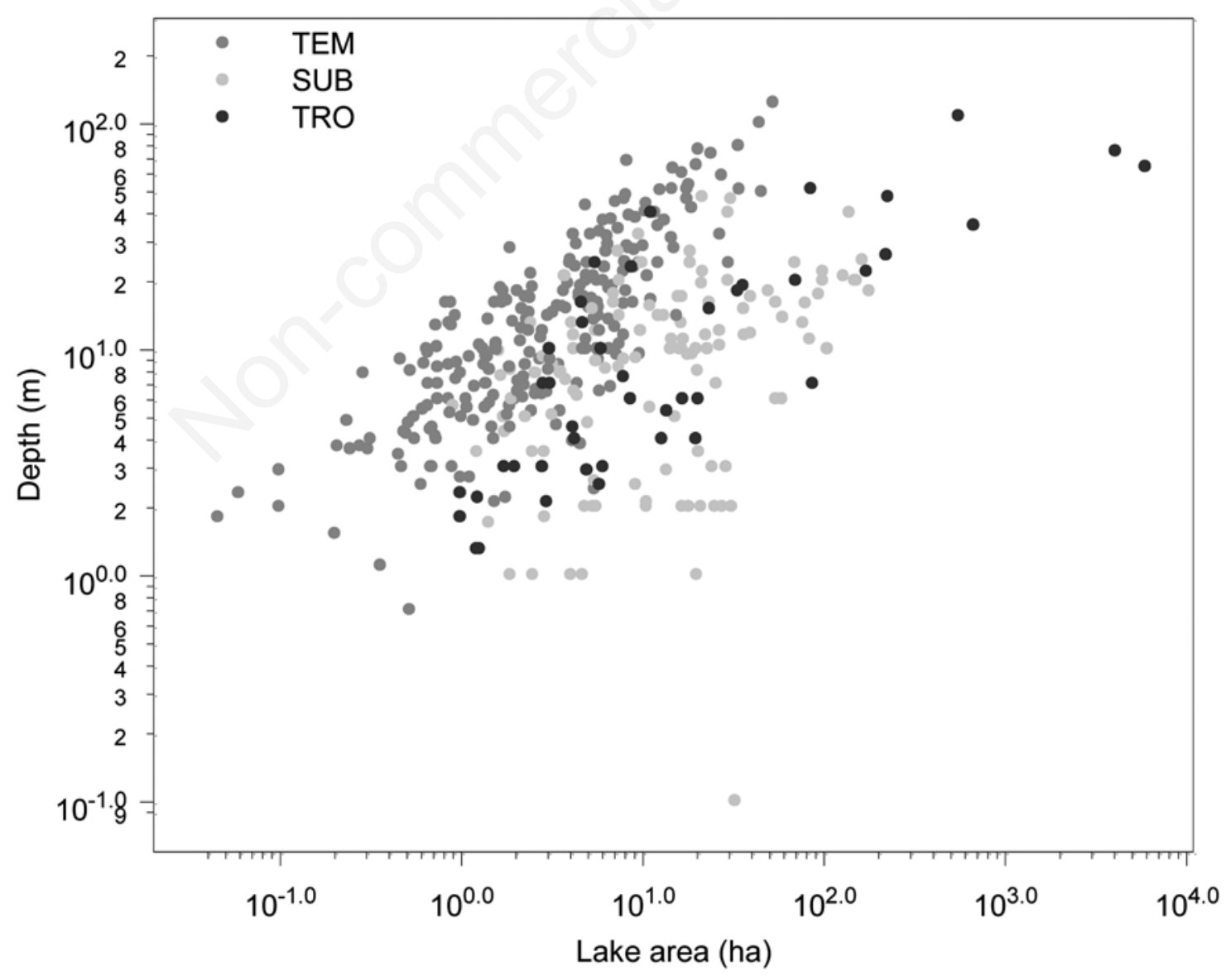

Fig. 1. Lake area against maximum depth for some tropical (black), temperate (grey) high-mountain and subarctic (light gray) lakes. 
subarctic environments, peat accumulation in the watersheds may increase DOC in lakes (e.g., Scotland, Scandinavia). In general, DOC correlates with the development of soils in the watersheds (Camarero et al., 2009b). In some tropical areas, thick organic soils develop (e.g., paramo vegetation; Fig. 3), and higher loads of allochthonous carbon than in temperate areas may be common (Buytaert et al., 2006). The available DOC measurements are still scarce (Eggermont et al., 2007); nevertheless, stained waters have been reported from the Andes (Ecuador, Colombia, Bolivia) and African ranges. High DOC has several implications, including a screening effect against high UV radiation (Aguilera et al., 2013), and an increased oxygen demand not related with the in-lake production. In stratified waters, the oxygen related to DOC decomposition may lead to thick hypoxic and anoxic layers in lakes that otherwise are oligotrophic (Fig. 4). These deep anoxic layers have very relevant implications in the biogeochemical pathways in these lakes and on the biota composition inhabiting them.

\section{LAKE PHYSICS - SEASONALITY}

Water column mixing and stratification present noteworthy differences between temperate and tropical lakes. The more apparent is the ice cover formation, which is a common feature in temperate high mountain lakes and is absent, or extremely rare, in tropical ones (Lewis, 2011).

In temperate lakes, the ice cover duration has influence at many levels, including biogeochemical cycling

\section{Cation proportion}

$\mathrm{Mg}^{2+}$

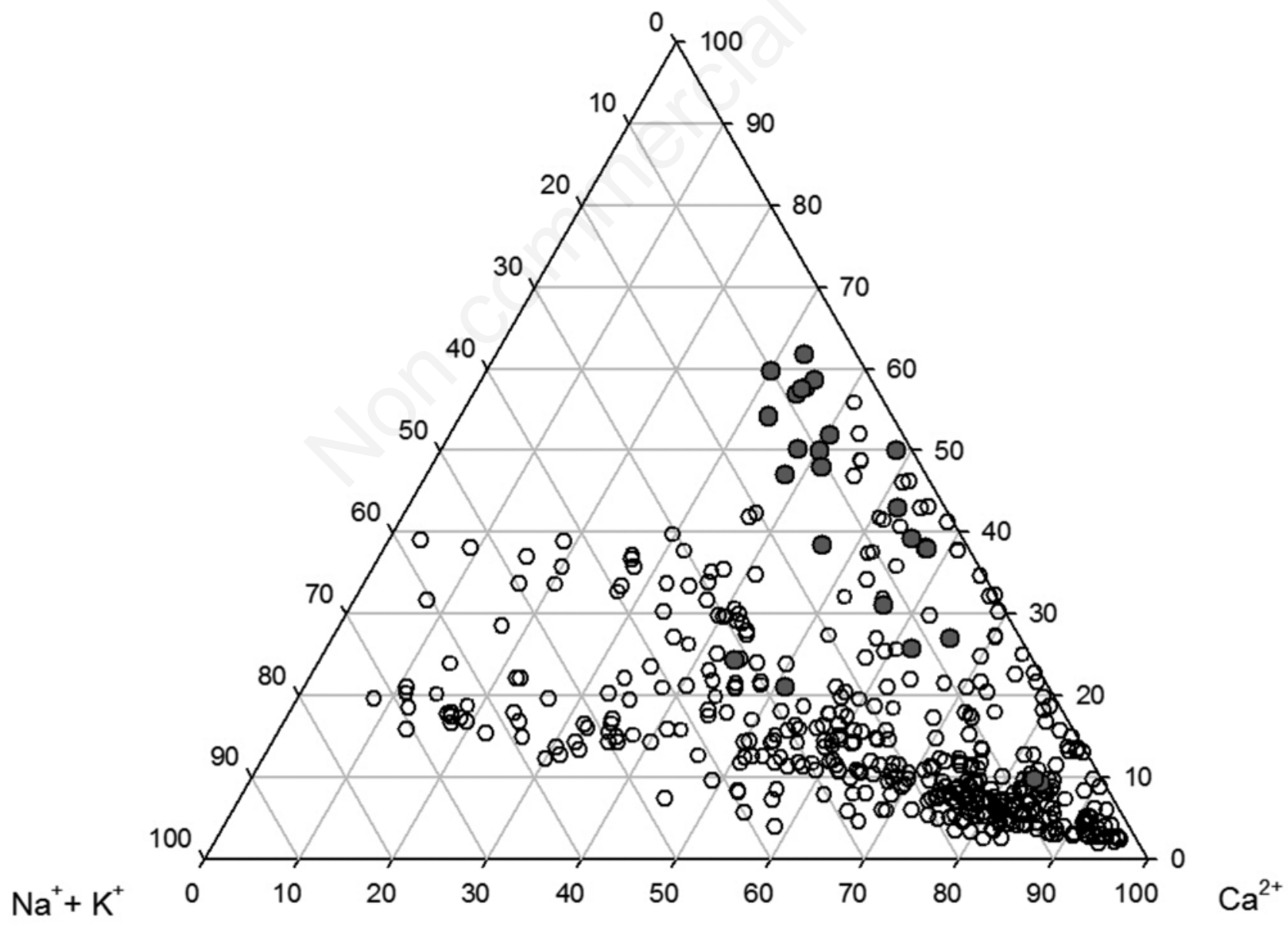

Fig. 2. Main cation proportions in some tropical high-mountain lakes (Donato-Rondón, 2010) plotted in a background of European alpine, and subarctic mountain lakes (empty circles) with varying basin bedrocks and maritime influence (Camarero et al., 2009b). 
(e.g., under ice nitrification (Catalan, 1992)), productive episodes (e.g., two or one event depending on ice cover duration (Catalan et al., 2002b)), biota composition (e.g., chrysophyte succession (Pla-Rabes and Catalan, 2011) and ecological thresholds in species distribution (i.e., $>190$ days ice duration; Catalan et al., 2009a). During the ice-free period, stable stratification is common in most of the temperate lakes due to their characteristic aspect ratio (deep compared to lake length) that make stable even relatively week thermoclines (Catalan et al., 2002b). Nonetheless, the stratification period is relatively short (a few months) compared to tropical lakes, in which stratification (or incomplete mixing of the water column) may last for most of the year (Fig. 4) (Donato-Rondón, 2010).

Weak temperature differences in tropical high mountain lakes have suggested general polymictic scenarios. However, the presence of a year round oxycline in many lakes indicates that mixing is seldom complete in many of them (Degefu and Schagerl, 2015a; Donato-Rondón, 2010). They episodically mix (even daily in the upper layers) but they rarely become completely mixed (Imberger, 1985). The aspect ratio of the lakes (deep compared to fetch) and the development of ephemeral thermoclines continuously mitigates wind driven turbulent transport and the homogenization of the water column. Mixing is mainly convective and driven by the high daily air-temperature fluctuations. Therefore, contrasting temperature and oxygen profiles occur between high-mountain tropical lakes and temperate ones (Fig. 4), with major consequences for the main biogeochemical pathways. In high-mountain tropical lakes with less developed soils, the marked oxygen gradients may not be present at any time of the year. In this cases, there is little water column structure as temperature differences between top and bottom may be $<1{ }^{\circ} \mathrm{C}$ (Alcocer et al., 2004). The biogeochemical patterns and dynamics in these lakes are more similar to the temperate lakes, although without the marked seasonal patterns that the existence of an ice-cover period confers. According to the studies available at present, it seems that one can expect a whole range of mixing regimes (i.e., monomixis, atelomixis, polymixis, meromixis) in high-mountain tropical lakes and transitional similar systems (Casallas and Gunkel, 2001). However, rather than struggle in phenomenological typologies and correlations, investigations would better move to improve process understanding. The ecological meaning of mixing regimes makes sense when other gradients are considered at the same time (e.g., light, oxygen, nutrients). At present, there is enough knowledge and data available to undertake a modelling exercise determining the main drivers and constraints of the observed regime differences among high-mountain lakes and which are the tipping points for changing from one to another.

The maximum water temperature achieved in high mountain tropical lakes may be not much higher than the maxima in temperate lakes. They all tend to remain below $20^{\circ} \mathrm{C}$. However, the heat content of the water column is higher in tropical lakes as higher temperatures are found at deeper layers and throughout most of the year; contrasting with the short summer warm epilimnion of temperate lakes. Due to the scarce oscillations of air temperature throughout the year, the annual head budget is low and stratification persists in tropical high-mountain lakes for many months. Lakes only mixing every few years may also occur. In fact, seasonality in tropical areas is provided by wet and dry seasons, which in the Andes have been driven by Pacific surface-sea air temperatures throughout the Holocene (Polissar et al., 2013). The resulting effect in the water column of lakes may depend on the changes in the direction and velocity of the wind and the influence of runoff changes in the water renewal of the lakes. Lake
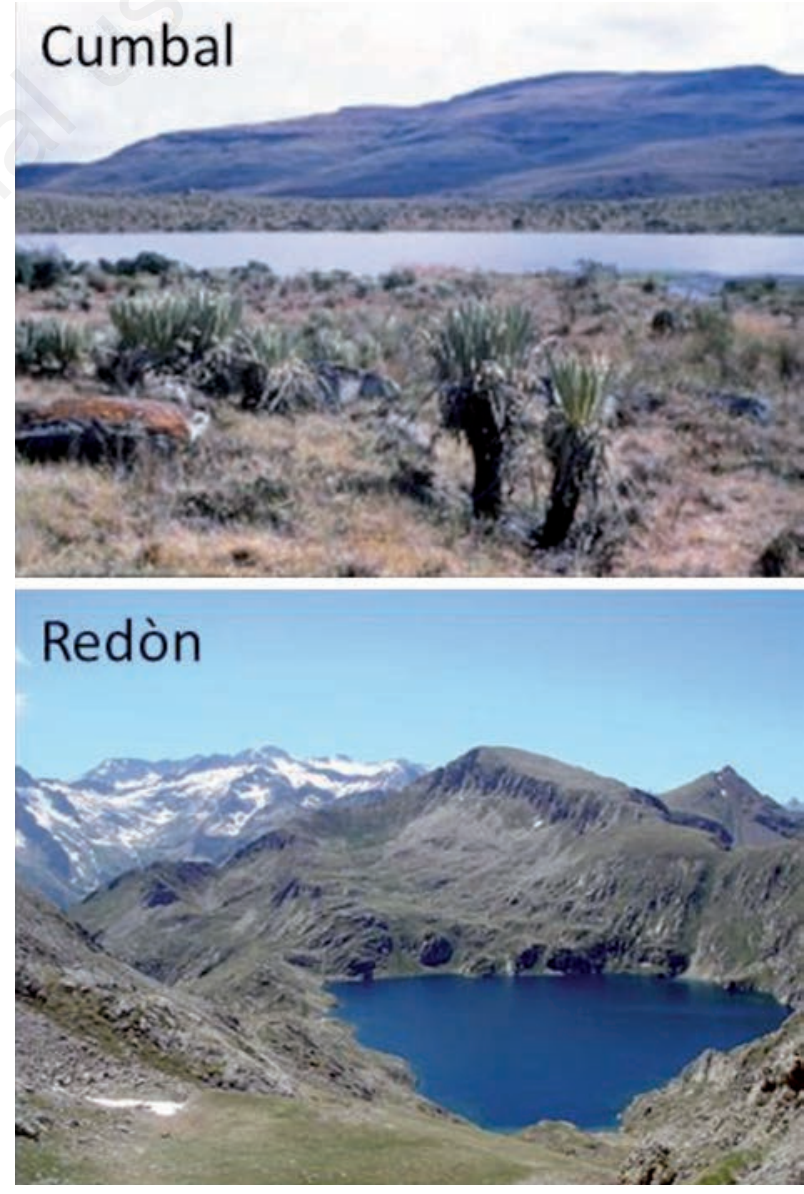

Fig. 3. Two examples of tropical and temperate high-mountain lakes, respectively: Lake Cumbal, Colombian Andes, $3424 \mathrm{~m}$ asl, surrounded by paramo vegetation; and Lake Redòn, Pyrenees, $2232 \mathrm{~m}$ asl, alpine grassland in the watershed. Photographs from John C. Donato and Marc Sala, respectively. 
size and watershed features may highly influence the final result. Lake Cumbal (Colombian Andes) achieves the largest difference between top and bottom temperature during the rainy period. And, during this period, the oxycline becomes stronger (Fig. 4).

The seasonal differences between tropical and temperate high-mountain lakes can be briefly summarize considering temperature and oxygen profiles (Fig. 4). Tropical lakes show relatively constant high temperature throughout the year but marked oxygen fluctuations; whereas in temperate lakes occurs the opposed: oxygen is relatively high and stable throughout the year (except in very deep layers), whereas temperature fluctuated markedly (about 10 degrees in the upper layers). The decline of air pressure with altitude (ca. 11\% per $\mathrm{km}$ ) and higher water temperature contributes to a lower water concentration of gasses at saturation in tropical lakes. This situation added to a higher oxygen demand, because of the inputs of allochthonous organic materials (e.g., paramo lakes) or reduced metals (e.g., underwater springs in volcanic lakes; Degefu and Schagerl, 2015a), determines the development of thick anoxic layers irrespectively of its internal primary production. The oxygen profiles may be similar to eutrophic and oligotrophic meromictic lakes; in the later, the contrast between the low trophic status and the sediments enriched in organic matter have been named as a pseudo-eutrophic lake stratification (Schmidt et al., 1998), which was obviously present before the onset of human eutrophying impact. Differences between nutrient-induced eutrophic states and these pseudo-eutrophic states might merit investigation.

Both, temperate and tropical lakes offer excellent opportunities for studies of physical processes with high detail and of their implications for biogeochemical and ecological processes. As mentioned, the high aspect ratio of high-mountain lakes enhance the importance of convec-

Cumbal Oxygen (mg L-1)

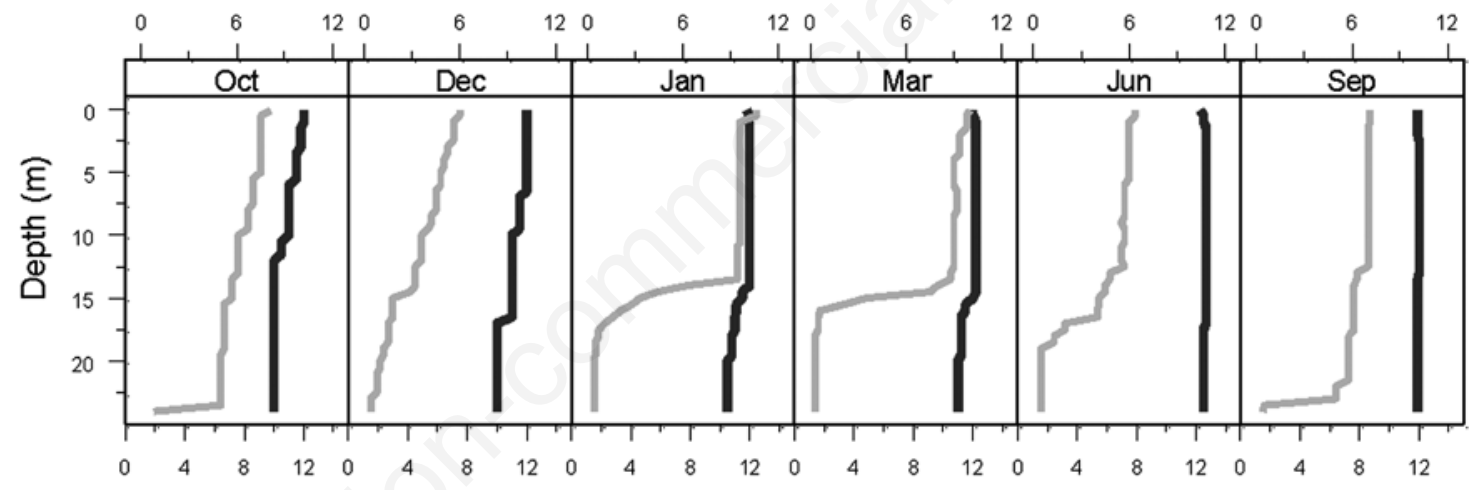

Redòn

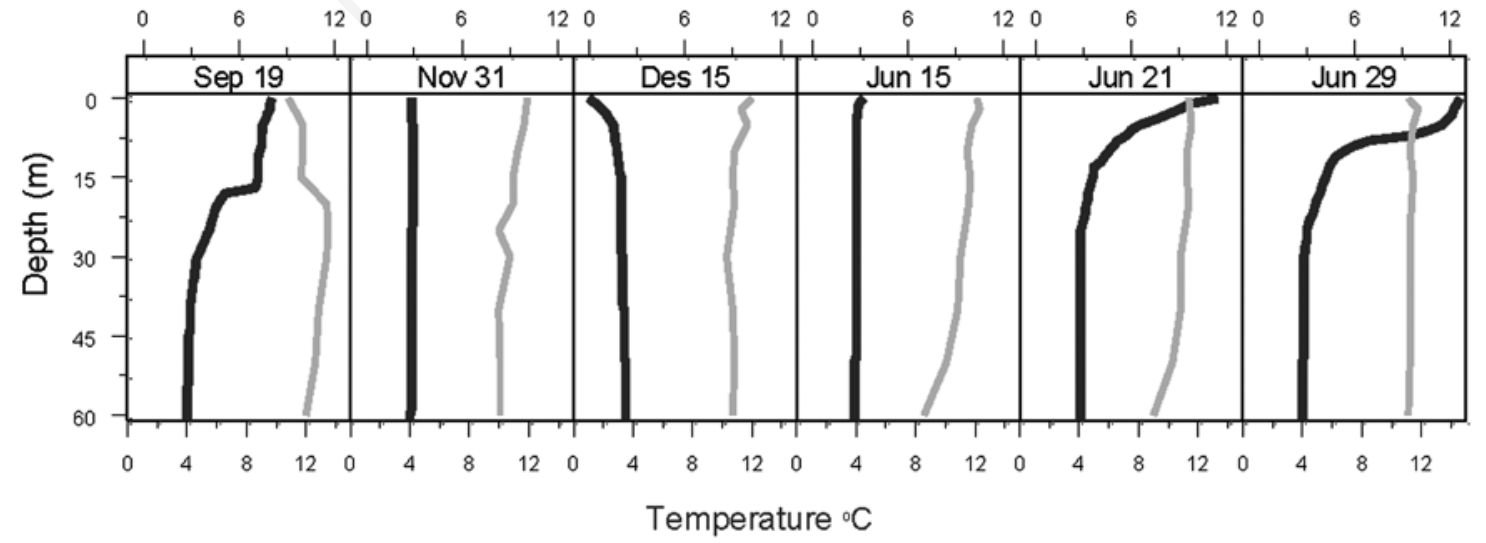

Fig. 4. Seasonal temperature (black) and oxygen (grey) profiles in Lake Cumbal in the Colombian Andes and Lake Redòn in the Pyrenees. Profiles in Cumbal were measured at 6 a.m. from October 1994 to September 1995 (Donato-Rondón, 2010). Profiles in Lake Redòn were measured around 12 a.m. from September 1984 to June 1985 (Catalan, 1988). Dates have been selected to illustrate typical seasonal profiles and the periods of rapid change. 
tive mixing, in contrast to the most studied systems in which wind-driven mixing is the most relevant. In tropical areas, air temperature differences between day and night may be larger than between monthly means. The night cooling may facilitate deep water column mixing (ca. 10$20 \mathrm{~m}$ deep, (Gunkel, 2000)), which can erode oxyclines and provide regular nutrient inputs to the upper layers, providing productive and general environmental conditions rather different than in stratified temperate lakes, in which the seasonal thermocline provides an effective barrier to the episodic mixing of the epilimnion (Catalan, 1988). On the other hand, the elevated importance of the boundaries also increases the relevance of transport by internal wave (Filonov et al., 2015), and mixing by wave breaking and the boundary layer excitation (Boegman, 2010).

\section{BIOGEOCHEMICAL PATHWAYS}

The biogeochemical dynamics between tropical and temperate lakes differs due to the two factors that we have already considered: the mixing and stratification temporal patterns and loadings of allochthonous carbon. Phosphorus loadings can be an additional third factor in volcanic regions that may force the common oligotrophic conditions of high-mountain lakes to more productive situations.

As mentioned above, the combination of prolonged stratification and high oxygen demand determines the presence of hypolimnetic thick anoxic layer in many high mountain tropical lakes. The hypoxia may be irrespective of whether the internal primary productivity is high (e.g., with high P loading) or low (when there are low nutrient inputs from the surroundings).

The presence of these thick anoxic layers has a strong influence in many biogeochemical pathways (Lewis, 2010). One of the consequences is a large potential for denitrification around the oxycline; therefore, in many tropical mountain lakes, nitrate concentration is below detection limit. On the other hand, the anoxic layer is a reservoir of ammonium (Degefu and Schagerl, 2015a; Donato-Rondón, 2010; Zapata-Anzola et al., 2006) and source to the upper layers, which may show episodically high concentrations $\left(>2-8 \mu \mathrm{mol} \mathrm{L}^{-1}\right)$. Similar high values are only found in some temperate lakes during the thaw period, with ammonium entering with snow melting water (Catalan, 1992). The high ammonium levels in tropical lakes can fuel nitrification at the oxycline and, the resulting nitrate, denitrification. Therefore, nitrogen losses from the aquatic system can be high and, nitrogen fixation may become crucial processes for maintaining the aquatic ecosystem activity. All in all, nitrogen cycling in high-mountain lakes has been insufficiently investigated and will merit more attention. The study of tropical N nitrogen limited sites may also provide some light about pristine conditions in temperate lakes, most of which have been strongly affected by atmospheric $\mathrm{N}$ deposition during the last decades (Baron et al., 2011).
A thick anoxic layer also facilitates that phosphorus and metals solubilize (Wann et al., 1997). This fact provides a higher internal loading of nutrients in tropical than in temperate high mountain lakes, which may sustain, in average, relatively high chlorophyll values throughout the year (Donato-Rondón , 2010). The highest chlorophyll values tend to occur a few meters above the oxycline (Fig. 4), where there is light but lower harmful radiation and nutrient supply from below. In the upper part of the anoxic layer, photosynthetic bacteria may growth (Nunez-Cardona et al., 2008). These autotrophic bacteria are probably confined to photic-zone fine sediments in the temperate lakes. New molecular techniques may unveil the relevance of this and other groups of bacterial autotrophs in both types of mountain lakes (Auguet et al., 2011).

In temperate lakes, deep chlorophyll maxima during stratification are also common. Primary production occurs below the seasonal thermocline (Catalan et al., 2002b). Epilimnetic waters are extremely poor in nutrients and receive high radiation that inhibits photosynthesis. The high UV proportion may results harmful to organisms (Sommaruga, 2001); yet high-mountain lake organism may be less sensitive than organisms normally exposed to lower doses (Halac et al., 1997; Helbling et al., 2001). The nutrient supply to these stratification chlorophyll maxima is lower than in tropical lakes. In deep lakes, the tropholytic layers are far deeper. In shallow lakes, nutrient release to the water column from the sediments is sealed by a biofilm of growing photosynthetic eukaryotic organisms, as enough irradiance reaches the bottom of the lake.

In both tropical and temperate lakes, chlorophyll maxima tend to occur at depths with 1 to $0.1 \%$ of the irradiance at the surface (Fig. 5). Maxima of phytoplankton biomass (i.e., biovolume) and chlorophyll are slightly decoupled in time and space as chlorophyll per unit of cell volume increases both with time after phytoplankton blooming, and with the decline of light availability (Felip and Catalan, 2000). Productivity maxima are also spatially decoupled from biomass ones; the former tend to occur some meters above the latter due to the continuous cell sinking. For this reason, oxygen maxima and chlorophyll maxima may also appear at slightly different depths. In tropical lakes, decoupling between chlorophyll and biomass may be exacerbated by steeper nutrient and light gradients that influence photosynthetic efficiency (PinillaA et al., 2006).

In temperate lakes, the seasonal peaks of primary production occur associated to overturn periods. If the length of the ice-free period is sufficiently long, two peaks occur: one at ice-off and another during the autumn overturn before the ice formation (Catalan et al., 2002b). These two productive peaks are internally fueled by the phosphorus recycling in the deep sediments; as a consequence, the amount of productivity is not independent between the 
two periods. If the spring mixing period is long, and thus spring productivity high, autumn productivity is low, irrespectively of the overturn mixing duration. Conversely, if spring mixing period is short, autumn productivity becomes greater than that during spring (Pla-Rabes and Catalan, 2011). Productivity temporal fluctuations in tropical lakes show higher frequency than in temperate ones due to the episodic partial (or complete) mixing of the water column. Occasionally, mixing of the whole column may increase phosphorus supply to the photic depth (Zapata-Anzola et al., 2006). However, response to this internal load may be hampered by the lack of nitrogen availability in some lakes (Donato-Rondón, 2010) (Casallas and Gunkel, 2001). There is much to investigate about $\mathrm{N}$ and $\mathrm{P}$ cycles interaction and influence on productivity in both tropical and temperate lakes. The relative atmospheric loadings of these nutrients are shifting at fairly high frequency (Camarero and Catalan, 2012).

\section{BIOTA}

The knowledge of the organisms inhabiting highmountain lakes is still reduced for both temperate and tropical regions. The biota of high-mountain lakes in tropical regions has a higher affinity for extratropical areas than those from lowland ecosystems (Löffler, 1962). For instance, in the tropical Andes many organisms are of boreal, Antarctic or neotropical origin. The number of endemism is low compared with the rich biota of the lowlands, although probably not sufficiently explored (Kotov et al., 2010). All in all, studies with modern molecular taxonomy might provide some surprises about this issue, particularly, for organisms with scarce morphological differentiation. High-mountain lake districts can be regarded as 3-D archipelagos in terms of metacommunity dynamics. Colonization of high altitude lakes may be difficult, particularly for large organisms. Moving upwards
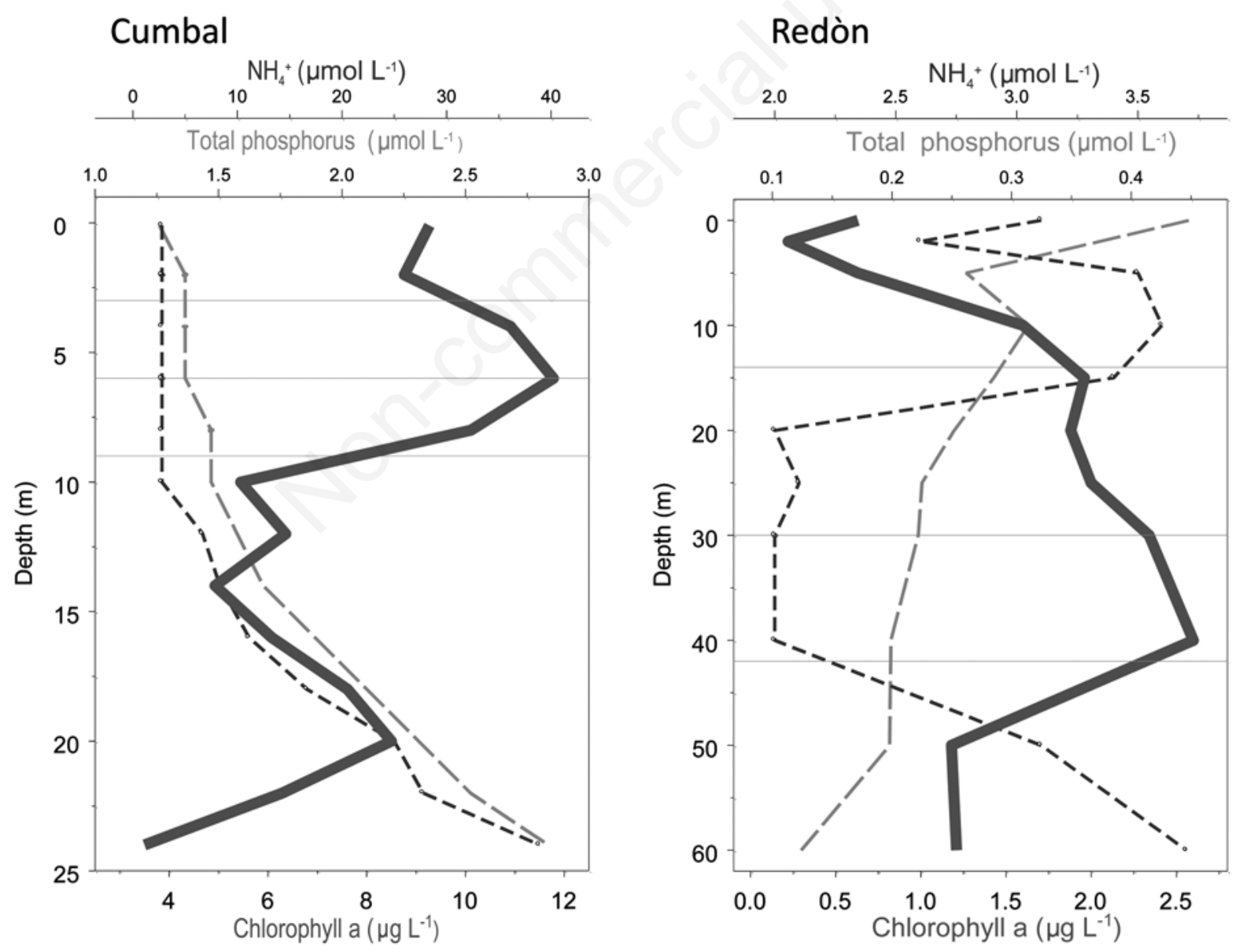

Fig. 5. Chlorophyll (black), ammonium (dashed dark grey) and total phosphorus (dashed light grey) profiles in Lake Cumbal (Colombian Andes, October 1994) and Lake Redòn (Pyrenees, August 1985). Horizontal lines indicate 10,1 and 0.1\% of irradiance at the surface. Note the different scaling of the axes. 
in the mountain implies difficulties of transport, accommodation to new, usually harsher, conditions, and shrinking suitable area. These issues have been only incipiently studied (De Mendoza et al., 2015). In any case, it may be worth to differentiate between the macroscopic and the microscopic ecosystems.

\section{The macroscopic ecosystem}

The presence of macrophytes is altitudinally limited in temperate lakes, the limit being similar to tree-line (Pulido et al., 2015). Water alkalinity is a major factor differentiating between communities. Isoetids in soft waters and potamids in more mineralized waters (Gacia et al., 1994). Aquatic mosses are common but only occasionally make large formations. Bogs and marshes directly connected to lakes are scarce and, if present, they only cover part of the littoral. In contrast, these palustrine formations are more frequent in tropical zones, probably because of the absence of a seasonal ice cover eroding the littoral. For instance, the transition from littoral to open waters may comprise several meters of vegetated habitats including Sphagnum, Distichia, Potamogeton and Isoetes zones. The changing conditions imposed by vegetation contribute significantly to explain the distribution of microscopic organism (e.g., Laguna de San Rafael, Colombian Andes; (Donato-Rondón, 2010). In temperate lakes, similar gradients may occur at the lower range of the lake distribution, but, in general, are less frequent and modest in development. The altitudinal distribution of macrophyte in tropical high-mountain waters require more attention, including the connection with montane areas (Carrillo et al., 2006).

Knowledge of high-mountain aquatic macroinvertebrates is still poor for temperate areas (Kernan et al., 2009) and poorer for tropical ones. One could expect marked differences according to the contrasting nature of the deep benthic zone and the littoral area between the lakes in the two zones. The altitudinal gradient is of particular concern for understanding the distribution of any particular group of aquatic macroinvertebrates (De Mendoza and Catalan, 2010). In tropical areas, lakes are located at higher altitude but seasonal fluctuations are smoother. Thus, the implications of the altitudinal gradient for groups of aquatic flying insects, and macroinvertebrates, in general, may differ from those in temperate zones. In fact, the "meaning" of altitude changes from one group of invertebrates to another as the altitudinal gradient has many environmental faces that affect live forms differently (De Mendoza and Catalan, 2010). Nevertheless, some groups seems to largely match the thermal gradient, particularly chironomids. The head capsule remains in the sediments of these diptera have been successfully used for air temperature past reconstructions in both temperate (Heiri et al., 2011) and tropical regions (Eggermont et al., 2010).
High mountain lakes are marginal or occasional habitats for amphibians. Their role may become more relevant the smaller the lake. However, the role of the amphibians within the lake food-web has not been adequately considered in high-mountain lakes. Increased coordination between limnological and amphibians' studies is required. In some tropical areas, there is a high number of species and endemisms. Species decrease markedly with altitude; however they show a narrow range of distribution compared to temperate zones (Bernal and Lynch, 2008). It would be interesting to compare how does the episodic use of the littoral of high-mountain lakes change from tropical to temperate areas given the contrasting seasonality.

Fish are not a natural component of most high-mountain lakes due to the physical impediments for arrival (lake isolation, waterfalls). However, in areas where human presence in the mountains occurred early in history, it may be common to find populations several centuries old (Miró and Ventura, 2013). Fish have a significant impact on amphibians and some invertebrates (Knapp, 2005), which may result in whole ecosystem changes that still merit further research (Knapp et al., 2005). In American tropical zones, the presence of fish at altitude may be due to uplift tectonics rather than dispersion by riverine corridors (Anderson and MaldonadoOcampo, 2011). Characiform fish occur over a broad elevation gradient (500-2100 m) in the Colombian Andes. The few species present at higher elevations, such as species of Grundulus and Bryconamericus, were associated to both lotic and lentic environments. Further taxonomic knowledge and their role in lacustrine food webs await further investigation. Some fish species may reach altitudes about $3500 \mathrm{~m}$ asl, (e.g., climbing catfishes (Astroblepidae)), but are mostly species from streams. The endemic species of the altiplano lakes (e.g. Orestias (Peru, Bolivia)) have been threatened by rainbow trout (Oncorhynchus mykiss) stocking (Aguilera et al., 2006). This exotic species may be causing food web changes in high mountain lakes of Bolivia, and other countries were have been introduced. Development of fishing tourism may progressively threaten fishless high mountain lakes throughout the world. Strong regulations are necessary, yet difficult to establish and apply.

Fish influence on zooplankton in high-mountain lakes is not as clear as in shallow eutrophic lakes. Daphnia species coexist with trout in many lakes in tropical and temperate mountain lakes. In some cases, diel vertical migration maintains patterns similar to lakes without fish (Aguilera et al., 2006) (Degefu and Schagerl, 2015b). Rare events, such a high fish mortality, may unveil topdown trophic cascades that otherwise remain controversial (Fetahi et al., 2011). Effects on large littoral crustaceans (e.g., amphipods, Eurycercus) could be more significant, yet evidence from field studies is still pending. 
More interestingly, a comprehensive analysis of the interaction between fish and zooplankton in cold and oligotrophic systems may show contrasting dynamics and tipping points with eutrophic and warm systems. Partial studies have shown a predation shift from macroinvertebrates (mainly chironomids) to planktonic zooplankton (cladocerans) as autumn proceeds and the former decline (Catalan et al., 2004).

\section{The microscopic ecosystem}

Crustaceans, at the limit of the microscopic ecosystem, are relatively poor in species in high-mountain lakes, particularly, the purely planktonic forms (Kernan et al., 2009). Distribution patterns related to the length of the ice-cover and size of the system have been described for temperate lakes (Catalan et al., 2009a). Phylogeographical patterns are being unveiled with the use of molecular techniques, which have shown the importance of founder effects despite the apparent high dispersal potential of these organisms (Ventura et al., 2014). Mountain lakes of northern South America are a region of intersection between faunistic elements of Austral-subantarctic and Holartic origin; among crustacean calonoids, species of boeckellids and diaptomids (Gaviria, 1989), respectively. In general, tropical high-mountain lakes can be seen as climatic islands for temperate cladocerans (Damme and Eggermont, 2011). The genus Daphnia, common in temperate areas, is rare in the tropics and bound to higher altitudes in Africa, where a few species are known to occur ca. $>3000 \mathrm{~m}$ asl. The Rwenzori and Mount Kenia cladocerans fauna can be considered a result of recruitment from temperate regions rather than in situ evolution. For instance, Lake Mahoma (Rwenzori M.) harbors a chydorid community that is typical for an acid boreal lake (Damme and Eggermont, 2011). Interesting questions about refuge, active colonization or disruptions can be raised around the crustacean communities of temperate and tropical high mountains. As mentioned, molecular tracers are the way to go (Ventura et al., 2014). It may be particularly interesting the comparison of the biogeographical patterns and process between the American western ranges, showing a latitudinal continuum, and the disrupted mountain distribution of Europa and Africa. In the Andes, incipient exploration of high mountain cladocerans has already provided an elevated number of endemisms (Kotov et al., 2010). Other organisms may result as interesting as crustaceans for biogeographical inquiries (e.g., chironomids; Eggermont and Verschuren, 2007). The presence of true planktonic assemblages depends on lakes size in both temperate and tropical lakes. Typical littoral crustaceans and rotifer dominate open water assemblages in temperate lakes below ca. 3 ha area (Catalan et al., 2009a). A similar threshold may exist for tropical ones (Dimas-Flores et al., 2008) although larger databases are required for statistical significance. Most living organisms in high-mountain lakes are microscopic both in pelagic and benthic zones. The knowledge of these organisms is still very limited, despite some comparative studies (Straskrabova et al., 2009). However, the existing studies seem to indicate marked differences related to the biogeochemical idiosyncrasy described for tropical lakes and sometimes higher nutrient loadings related to volcanic substrates (BanderasTarabay, 1997).

Concerning phytoplankton, rich desmidiaceae assemblages is a feature of many high-mountain tropical lakes that is lacking in temperate ones (Banderas-Tarabay et al., 1991; Rivera et al., 2005). The reason may be multivariate. In relatively small lakes, the higher influence of palustrine environments surrounding the lakes, which are rich in desmidiaceae, may increase the presence of ticoplanktonic elements. However, this cannot be the cause in large lakes. In them, partial diurnal mixing has been suggested as the driver (Degefu and Schagerl, 2015a). Although this may have influence, chemical factors such as the abundance of metals and humic substances may also be relevant. An experimental investigation is necessary. On the other hand, the hypoxic environments rich in metals favor euglenophytes (i.e., Trachelomonas), which are rare in temperate lakes. In fact, the marked changing conditions with depth define the first axis of phytoplankton variation in tropical high-mountain lakes (Donato-Rondón, 2010). Seasonal variation, which is the first axis in temperate lakes, appears as a second component driven by changes in rain and the wind. At this respect, cyanobacteria may substitute chlorophytes during periods of stratification (Donato-Rondón, 2010). Furthermore, low levels of irradiance in the hypoxic zone favor the growth of photosynthetic bacteria (e.g. Thiocapsa (Chromatiaceae) (Nunez-Cardona et al., 2008)). Interestingly, the changes in the populations of these organisms may be traced back because of the preservation of their bacteriochlorophylls and characteristic carotenoids in the sediments (Buchaca and Catalan, 2007). Other groups of microscopic eukaryotes (e.g., ciliates and other heterotrophic groups) have been less studied, although there are some comparative studies (Macek et al., 2006). There is evidence of a hidden phytoplankton diversity as indicate by the presence of stomatocyst assemblages in lake sediments (Vilaclara et al., 2005). Overall, current molecular techniques allow for comprehensive studies of the planktonic and microscopic benthic communities. The use of these techniques is incipiently opening a new view of the microscopic ecosystem of mountain lakes (Auguet and Casamayor, 2013). This fact affects not only prokaryotes (Callieri et al., 2013) but also microscopic eukaryotes that were extremely difficult to determine with traditional methods (Triado-Margarit and Casamayor, 2012). There is still a wealth of work to do for merging knowledge from tradi- 
tional and new molecular approaches. The new techniques may also facilitate the study of microhabitats that are difficult to sample and observe appropriately; for instance, biofilms (Bartrons et al., 2012) and slush layers in the ice and snow cover (Llorens-Mares et al., 2012). More interestingly, the molecular methods allow for merging biogeochemical and biodiversity studies in a truly comprehensive ecological approach (Vila-Costa et al., 2014), which also open new views to the macroscopic past (Boessenkool et al., 2014). In that sense, tropical mountain lakes provide an extremely diverse catalogue of biogeochemical settings. Which includes sulfur and metal cycles if there is volcanic influence (Demergasso et al., 2010) or nitrogen cycles in high DOC lakes, for instances.

\section{MOUNTAIN LAKES IN A CHANGING WORLD}

\section{Landscape culturization}

Even in highly populated continents, high altitude mountains suggest landscapes scarcely influenced by humans. However, paleoecological studies (including paleolimnology, but also archeology and other disciplines reconstructing the past) indicate that human influence on the landscape started early in prehistoric times (Kirch, 2005). In European high mountain areas, artificial enhancement of alpine meadows started several thousand years ago (Roepke et al., 2011). In tropical areas, human influence on the landscape has also been reported to occur at least since mid-Holocene (Niemann and Behling, 2009; Niemann et al., 2009). In the central Andes, pastoralism of laminoids at high altitudes $(>3000$ $\mathrm{m}$ asl) started at least 3000 years ago (Flores-Ochoa, 1979). Yet climate influence on fire regimes is complex throughout the Holocene (Marlon et al., 2013), early landscaoe impacts have been related to the human use of fire in temperate and some tropical areas (Tinner et al., 2005). The last millennium has been a period of large intervention in mountain ecosystems in many parts of the world (Butzer and Butzer, 1997). In Europe, MiddleAges were probably the period of higher human impact in the mountains throughout history; whereas in America the peak has been within the last centuries or is currently occurring (Wunder, 1996). The existence of plateaus in some ranges has facilitated agricultural development at high altitude and likely eutrophication and erosion processes, which are reflected in the sediments (Gunkel, 2003). There is still much to investigate on human intervention in high mountain landscapes, even in areas that at present result apparently pristine. In fact, there are places where human intervention in the landscape has no signature in the lake sediments (Schueler et al., 2012). However, huge changes at lower altitude (Sarmiento, 2000), due to agriculture and forestry development, may have had relevant implications in high- lands through local climate modification, animal species redistribution and connectivity between ecosystems (Etter et al., 2008). Traditional land-use in high-mountains is changing throughout the planet for multiple reasons. In some areas, complex trade-offs may occur between local and global ecosystem services. For instance, in some tropical areas incentive for pine tree plantations for mitigating global change may be in conflict with other ecological benefits of alternative land use (Balthazar et al., 2015).

The constructions of channels modifying the watershed hydrology in historical times were mostly affecting grazing wetlands (e.g., bofedales (Andes), borreguiles (Sierra Nevada, Spain). Lakes were usually not affected until the industrialization and the establishment of hydropower stations in mountain valleys. High dams were built and tunnels communicating lakes excavated in many temperate mountain ranges during the $20^{\text {th }}$ century. In some areas, only a few large lakes were not impacted. Dams are always controversial, with major trait-off between conservation and economic interests. High-mountain systems may be marginal to nowadays major dam building plans in some parts of the planet (e.g. Amazon Andes (Finer and Jenkins, 2012)); nevertheless, some watchful attitude among the scientific community may not be useless.

\section{Fish stocking}

As mentioned, high mountain lakes are naturally fishless with few exceptions as fish cannot swim upward high waterfalls recurrently present in mountain streams. In Europe, there is documentary evidence that fish stocking started at least 500 years ago in parts of the Alps and the Pyrenees (Miró and Ventura, 2013). The activity has been facilitated in recent decades by transport facilities and increase interest for sport fishing (Miró and Ventura, 2015).

Eradication of fish using gill nets in small mountain lakes is possible (Knapp and Matthews, 1998) and lake communities seem to quickly respond to the action (Knapp et al., 2005). However, fish stocking over large areas is primary a social affair. In particular, there is a need of further coordination between amphibian studies and limnological ones. Two threats are influencing the actual state of amphibian in tropical and temperate mountain lakes: infection by a chytrid fungus and predation pressure by stocked fish or directly upon some species (De La Riva and Reichle, 2014). Studies and conservation actions are both urgently required.

Stocking with a main fish species for sport and touristic fishing may trigger unexpected behaviors, such as the facilitation by the fishermen of the dispersal of other smaller fish species as food (e.g. minnows in the Pyrenees (Miró and Ventura, 2015), Grundulus above $3000 \mathrm{~m}$ in the Colombian Andes), with increasing effect on the lake's community. 


\section{Atmospheric contamination}

Beyond local influence, high mountain lakes have become paradigmatic examples of pollution by long-term atmospheric transport (Catalan et al., 2013a). The first evidence was acidification (Psenner and Schmidt, 1992). Many high mountain lakes in temperate zones are located on crystalline bedrock and, as a consequence, show scarce acid neutralizing capacity (ANC) (Psenner and Catalan, 1994). During the industrialization burst in the 1950's many high mountain areas in temperate zones received acid deposition. The critical load was exceeded, and lake ecosystems were severely affected (Baron et al., 2011; Curtis et al., 2005). Since then, awareness of the importance of the atmospheric loadings for these systems have steadily increased. Interest has extended to other contaminants [metals (Camarero et al., 2009a), persistent organic pollutants (Arellano et al., 2015)], and to the general effects of nutrients (Camarero and Catalan, 2012) and dust (Reche et al., 2009). In tropical areas, the atmospheric deposition is likely to be also important for high mountain lake ecosystems. In some mountain ranges, marine and volcanic sources may be episodically quite relevant as found in other areas (Guevara et al., 2010). On the other hand, there are several large urban areas located at altitudes of several thousand meters, which can be source of a diversity of pollutants. Extensive agriculture over large areas (e.g. Brazil) may become sources of organic contaminants that are used massively (Meire et al., 2012), even if they are not persistent. Some of these contaminants may show typical cold-trapping altitudinal gradients (Shunthirasingham et al., 2011). Recent studies in the Rwenzori Mountains of Uganda show that the lakes have been contaminated by $\mathrm{Hg}$ from atmospheric deposition starting at least by the late nineteenth century (Yang et al., 2010). The $\mathrm{Hg}$ accumulation increased by about 3 -fold since the mid-nineteenth century, similarly to other remote regions worldwide. Paleolimnology, combined with historical and archeological information, may provide records of atmospheric pollution impacts in tropical areas in which mining activities developed at large scale. European records indicate that past societies had already an elevated capacity for increasing atmospheric metal loading at high mountain lakes (Camarero et al., 1998).

\section{Climate change}

During the last decades, warming has been higher in some mountain areas than the mean of the planet (Mountain Research Initiative, 2015). Among others, glacier retreat is the most visible effect (Frezzotti and Orombelli, 2014; Kaser et al., 2004; Solomina et al., 2015), in some cases compromising mountain services to large populations (Bradley et al., 2006; Bury et al., 2011). Loss of permafrost, and glacier retreat are responsible for accelerated mass wasting and some catastrophic slope failures in high mountains in recent decades (Lopez-Moreno et al., 2014). Moraine dams are vulnerable to failure and outburst floods erode, transport, and deposit large amounts of sediments over long distances. These floods have claimed thousands of lives in the Andes and Himalayas and continue to be a hazard in these and other mountain ranges (Clague, 2009). Changes in sediment accumulation patterns may be one of the earliest evidences of climatic change in both tropical and temperate lakes. Glaciers in the humid tropical Andes seem to be more sensitive to climate fluctuations than those on drier southernmost areas (Rodbell et al., 2009). In African tropical areas, glacier shrinking and disappearance may produce a water level regime shift through-flow high mountain lakes, in which glacier meltwater in the main source of replenishment during dry season (Rietti-Shati et $a l ., 2000$ ), even though glacier water may be of minor relevance for total alpine river discharge (Taylor et al., 2009). Lakes fed by glacier water appear more sensitive to recent warming than those without glacier influence (Russell et $a l ., 2009$ ) and thus may be better indicators of current climate change pace in the area.

High mountain lakes are sentinels of on-going changes at regional and global scales (Battarbee et al., 2002). Both, time series of observations and high-resolution studies of lake sediments have provided evidence that responses to the recent warming is already occurring (Catalan et al., 2013b; Catalan et al., 2002a; Rühland et al., 2015). Recently, this evidence has extended to some tropical high mountain lake regions (Michelutti et al., 2015), although in others no recent changes since the end of the Little Ice Age are evident (Cuna et al., 2014). Regardless, in both areas, tropical and temperate, there is still much to investigate as warming may have synergic effects with atmospheric emissions, and watershed dynamics may largely differ among sites. The lakes and peatlands (Skrzypek et $a l ., 2011)$ provide an integrated record of the watershed dynamics that is far from being explored and understood.

Both in temperate and tropical areas, potential changes in precipitation are particularly problematic. Not only because precipitation projections are more uncertain that those for temperature but also because the effects of changing precipitation in high mountains are dependent on the season when they occur. Whether snow or rainfall predominate, changes hydrological seasonality (Anderson, 2012). Improving our knowledge of the ecological effects of precipitation should occupy a preferential position in the agenda for environmental research in high mountain lakes, both in temperate (Booth et al., 2006) and tropical zones (Bonnefille and Chalie, 2000). Evidence from the past shows that fire regimes in subalpine and montane zones depend on precipitation conditions (Beaty and Taylor, 2009; Biagioni et al., 2015), beyond human constraints. Understanding flood regimes may be of im- 
mediate application to current climate change hazards in mountain areas again both in tropical and temperate zones (Carey, 2005).

\section{CONCLUSIONS}

\section{Scientific and social value of mountain lakes}

High mountain lakes throughout the planet have many features in common; perhaps they are the most comparable type of ecosystems across continents. Accordingly, studies in one location can provide fundamental knowledge for many sites across the globe. High mountain lakes can be considered extreme ecosystems according to the environmental conditions that the organisms face (Catalan et al., 2006). The physiological, ecological and evolutionary consequences of high dilution, low temperature, high radiation, unusual water chemistry, large periods of darkness or extended periods of hypoxia are some of the general topics that can be studied. High mountain lakes provide an excellent natural experimental setting for any of these topics (Tab. 1).

On the other hand, the airshed-lake sediment continuum constitutes an excellent model for integrative studies across aerial and aquatic ecosystems (Catalan et al., 2014). Interestingly, this approach applies to both theoretical and applied topics and may find, therefore, its way into general society interest (Catalan, 2015). Global change understanding, with its many facets, requires such an approach. The mountain lake district concept complements the ecosystemic view, increasing the functional scale to regions.

Mountain lakes also hold cultural and recreational values. Lakes in a mountain landscape are pleasant to many cultures across the globes. Esthetic, cultural and spiritual values are associated with mountain lakes in both temperate and tropical areas. Some sites result particularly significant. For instance, Laguna de Guatavita (Colombia) was related to the Muiscas' culture until the $16^{\text {th }}$ Century (Rivera Rondon et al., 2010). Muiscas regarded life and death as transitions between terrestrial activity and aquatic dormancy. Various high-altitude lagoons were treated as sacred places. There, gods were worshiped and paid tributes in the form of figurines, fashioned from wood, cotton, stone and, especially, gold, called tunjos, and emeralds. The famous legend of El Dorado originated from the Muiscan practice of anointing new chiefs with turpentine and gold dust, from forehead to feet, so that they resembled a shaft of radiant light. The new chief became purified by bathing in the limpid waters of the Guatavita lagoon, from which activity, he drew the strength and wisdom necessary to govern his people with due justice (Perdomo, 1989). The ablutions attracted the pecuniary interest of postColumbian conquistadores $(1625)$ and $19^{\text {th }}$ and $20^{\text {th }}$ century national and foreign entrepreneurs. Photographic evidence
(1911) indicates the lake's complete draining by an English company (1909), which excavated a channel across half of the mountain to empty the lake (Ramírez, 1975). Beyond circumstantial religious or petty interests, high mountain lakes possess aesthetical, cultural and spiritual values of broad consensus among people of contrasting origin and beliefs. Perhaps, this is a further argument to use them as sentinels of the current global change.

\section{ACKNOWLEDGMENTS}

We are thankful to our colleagues that had shared our research in high mountain lakes during the last decades. We acknowledge support from research grants LACUS (Ministerio de Economía y Competividad, CGL201345348-P) and GECA (Generalitat de Catalunya, 2014 SGR 1249). This paper was planned as a follow-up of the VI Congreso Nacional de Limnologia in Mexico, JC thanks the kind invitation to participate.

\section{REFERENCES}

Aguilera X, Declerck S, De Meester L, Maldonado M, Ollevier F, 2006. Tropical high Andes lakes: A limnological survey and an assessment of exotic rainbow trout (Oncorhynchus mykiss). Limnologica 36:258-268.

Aguilera X, Lazzaro X, Coronel JS, 2013. Tropical high-altitude Andean lakes located above the tree line attenuate UV-A radiation more strongly than typical temperate alpine lakes. Photochem. Photobiol. Sci. 12:1649-1657.

Alcocer J, Oseguera LA, Escobar E, Peralta L, Lugo A, 2004. Phytoplankton biomass and water chemistry in two highmountain tropical lakes in central Mexico. Arct. Antarct. Alp. Res. 36:342-346.

Anderson L, 2012. Rocky Mountain hydroclimate: Holocene variability and the role of insolation, ENSO, and the North American Monsoon. Glob. Planet. Change 92-93:198-208.

Anderson EP, Maldonado-Ocampo JA, 2011. A Regional Perspective on the Diversity and Conservation of Tropical Andean Fishes. Conserv. Biol. 25:30-39.

Arellano L, Fernández P, Fonts R, Rose NL, Nickus U, Thies H, Stuchlík E, Camarero L, Catalan J, Grimalt JO, 2015. Increasing and decreasing trends of the atmospheric deposition of organochlorine compounds in European remote areas during the last decade. Atmos. Chem. Phys. 15:6069-6085.

Auguet JC, Casamayor EO, 2013. Partitioning of Thaumarchaeota populations along environmental gradients in high mountain lakes. FEMS Microbiol. Ecol. 84:154-164.

Auguet JC, Nomokonova N, Camarero L, Casamayor EO, 2011. Seasonal Changes of Freshwater Ammonia-Oxidizing Archaeal Assemblages and Nitrogen Species in Oligotrophic Alpine Lakes. Appl. Environ. Microbiol. 77:1937-1945.

Balthazar V, Vanacker V, Molina A, Lambin EF, 2015. Impacts of forest cover change on ecosystem services in high Andean mountains. Ecol. Indicators 48:63-75.

Banderas-Tarabay AG, 1997. Phycoflora of the tropical highmountain lake El Sol, Central Mexico, and some biogeographical relationships. Hydrobiologia 354:17-40.

Banderas-Tarabay A, Villela RG, Espino GD, 1991. Limnolog- 
ical aspects of a high-mountain lake in Mexico. Hydrobiologia 224:1-10.

Barker PA, Perrott RA, Street-Perrott FA, Huang Y. 2001. Evolution of the carbon cycle in Lake Kimilili, Mt Elgon, Kenya, since 14000 cal. yr BP: a multiproxy study, p. 7794. In: K. Heine (ed.), Palaeoecology of Africa and the Surrounding Islands. CRC Press.

Baron JS, Driscoll CT, Stoddard JL, Richer EE, 2011. Empirical critical loads of atmospheric nitrogen deposition for nutrient enrichment and acidification of sensitive US lakes. Bioscience 61:602-613.

Bartrons M, Catalan J, Casamayor EO, 2012. High bacterial diversity in eplithic biofilms of oligotrophic mountain lakes. Microb. Ecol. 64:860-869.

Battarbee RW, Thompson R, Catalan J, Grytnes JA, Birks HJB, 2002. Climate variability and ecosystem dynamics of remote alpine and arctic lakes: the MOLAR project. J. Paleolimnol. 28:1-6.

Beaty RM, Taylor AH, 2009. A 14000 year sedimentary charcoal record of fire from the northern Sierra Nevada, Lake Tahoe Basin, California, USA. Holocene 19:347-358.

Bernal MH, Lynch JD, 2008. Review and analysis of altitudinal distribution of the Andean anurans in Colombia. Zootaxa 1826:1-25.

Biagioni S, Wuendsch M, Haberzettl T, Behling H, 2015. Assessing resilience/sensitivity of tropical mountain rainforests towards climate variability of the last 1500 years: The longterm perspective at Lake Kalimpaa (Sulawesi, Indonesia). Rev. Palaeobot. Palyno. 213:42-53.

Bird BW, Kirby ME, 2006. An alpine lacustrine record of early Holocene North American Monsoon dynamics from Dry Lake, southern California (USA). J. Paleolimnol. 35:179-192.

Boegman L, 2010. Internal waves, p. 133-152. In: G.E. Likens (ed.), Lake ecosystem ecology: a global perspective. Academic Press.

Boessenkool S, Mcglynn G, Epp LS, Taylor D, Pimentel M, Gizaw A, Nemomissa S, Brochmann C, Popp M, 2014. Use of ancient sedimentary DNA as a novel conservation tool for high-altitude tropical biodiversity. Conserv. Biol. 28:446-455.

Bonnefille R, Chalie F, 2000. Pollen-inferred precipitation timeseries from equatorial mountains, Africa, the last $40 \mathrm{kyr}$ BP. Glob. Planet. Change 26:25-50.

Booth RK, Notaro M, Jackson ST, Kutzbach JE, 2006. Widespread drought episodes in the western Great Lakes region during the past 2000 years: Geographic extent and potential mechanisms. Earth Planet. Sc. Lett. 242:415-427.

Bradley RS, Vuille M, Diaz HF, Vergara W, 2006. Threats to water supplies in the tropical Andes. Science 312:1755-1756.

Buchaca T, Catalan J, 2007. Factors influencing the variability of pigments in the surface sediments of mountain lakes. Freshwater Biol. 52:1365-1379.

Bury JT, Mark BG, Mckenzie JM, French A, Baraer M, Huh KI, Zapata Luyo MA, Gomez Lopez RJ, 2011. Glacier recession and human vulnerability in the Yanamarey watershed of the Cordillera Blanca, Peru. Clim. Change 105:179-206.

Bush MB, Hansen BCS, Rodbell DT, Seltzer GO, Young KR, Leon B, Abbott MB, Silman MR, Gosling WD, 2005. A 17000-year history of Andean climate and vegetation change from Laguna de Chochos, Peru. J. Quaternary Sci. 20:703-714.

Butzer KW, Butzer EK, 1997. The 'natural' vegetation of the
Mexican Bajio: Archival documentation of a 16th-century savanna environment. Quaternary Int. 43/44:161-172.

Buytaert W, Celleri R, De Bievre B, Cisneros F, Wyseure G, Deckers J, Hofstede R, 2006. Human impact on the hydrology of the Andean paramos. Earth-Sci. Rev. 79:53-72.

Callieri C, Coci M, Corno G, Macek M, Modenutti B, Balseiro E, Bertoni R, 2013. Phylogenetic diversity of nonmarine picocyanobacteria. FEMS Microbiol. Ecol. 85:293-301.

Camarero L, Botev I, Muri G, Psenner R, Rose N, Stuchlik E, 2009a. Trace elements in alpine and arctic lake sediments as a record of diffuse atmospheric contamination across Europe. Freshwater Biol. 54:2518-2532.

Camarero L, Catalan J, 1996. Variability in the chemistry of precipitation in the Pyrenees (northeastern Spain): Dominance of storm origin and lack of altitude influence. J. Geophys. Res-Atmos. 101:29491-29498.

Camarero L, Catalan J, 2012. Atmospheric phosphorus deposition may cause lakes to revert from phosphorus limitation back to nitrogen limitation. Nat. Commun. 3:1118-1118.

Camarero L, Masque P, Devos W, Ani-Ragolta I, Catalan J, Moor HC, Pla S, Sanchez-Cabeza JA, 1998. Historical variations in lead fluxes in the Pyrenees (northeast Spain) from a dated lake sediment core. Water Air Soil Pollut. 105:439-449.

Camarero L, Rogora M, Mosello R, Anderson NJ, Barbieri A, Botev I, Kernan M, Kopacek J, Korhola A, Lotter AF, Muri G, Postolache C, Stuchlik E, Thies H, Wright RF, 2009b. Regionalisation of chemical variability in European mountain lakes. Freshwater Biol. 54:2452-2469.

Carey M, 2005. Living and dying with glaciers: people's historical vulnerability to avalanches and outburst floods in Peru. Glob. Planet. Change 47:122-134.

Carrillo Y, Guarin A, Guillot G, 2006. Biomass distribution, growth and decay of Egeria densa in a tropical high-mountain reservoir (NEUSA, Colombia). Aquat. Bot. 85:7-15.

Casallas JE, Gunkel G, 2001. [Algunos aspectos limnológicos de un lago altoandino: el lago San Pablo, Ecuador].[Article in Spanish]. Limnetica 20:215-232.

Catalan J, 1988. Physical properties of the environment relevant to the pelagic ecosystem of a deep high-mountain lake (Estany Redó, Central Pyrenees). Oecol. aquat. 9:89-123.

Catalan J, 1991. The relationship between the functional anatomy of lakes and primary production. Oecol. aquat. 10 .

Catalan J, 1992. Evolution of dissolved and particulate matter during the ice-covered period in a deep, high-mountain lake. Can. J. Fish. Aquat. Sci. 49:945-955.

Catalan J, 2015. Tracking long-range atmospheric transport of trace metals, polycyclic aromatic hydrocarbons, and organohalogen compounds using lake sediments of mountain regions, p. 263-322. In: J.M. Blais, M.R. Rosen and J.P. Smol (eds.), Environmental contaminants. Developments in paleoenvironmental research. Springer.

Catalan J, Ballesteros E, Gacia E, Palau A, Camarero L, 1993. Chemical composition of disturbed and undisturbed highmountain lakes in the Pyrenees - a reference for acidified sites. Water Res. 27:133-141.

Catalan J, Barbieri MG, Bartumeus F, Bitusik P, Botev I, Brancelj A, Cogalniceanu D, Manca M, Marchetto A, Ognjanova-Rumenova N, Pla S, Rieradevall M, Sorvari S, Stefkova E, Stuchlik E, Ventura M, 2009a. Ecological thresholds in European alpine lakes. Freshwater Biol. 54:2494-2517. 
Catalan J, Bartrons M, Camarero L, Grimalt JO, 2013a. Mountain waters as witnesses of global pollution, p. 31-67. In: P. Pechan and G.E.d. Vries (eds.), Living with water: targeting quality in a dynamic world. Springer.

Catalan J, Camarero L, Felip M, Pla S, Ventura M, Buchaca T, Bartumeus F, Mendoza GD, Miró A, Casamayor EO, Medina-Sánchez JM, Bacardit M, Altuna M, Bartrons M, Quijano DDD, 2006. High mountain lakes: extreme habitats and witnesses of environmental changes. Limnetica 64:123-145.

Catalan J, Curtis CJ, Kernan M, 2009b. Remote European mountain lake ecosystems: regionalisation and ecological status. Freshwater Biol. 54:2419-2432.

Catalan J, Pla-Rabés S, García J, Camarero L, 2014. Air temperature-driven $\mathrm{CO}_{2}$ consumption by rock weathering at short timescales: Evidence from a Holocene lake sediment record. Geochim. Cosmochim. Acta 136:67-79.

Catalan J, Pla-Rabés S, Wolfe AP, Smol JP, Rühland KM, Anderson NJ, Kopáček J, Stuchlík E, Schmidt R, Koinig KA, Camarero L, Flower RJ, Heiri O, Kamenik C, Korhola A, Leavitt PR, Psenner R, Renberg I, 2013b. Global change revealed by palaeolimnological records from remote lakes: A review. J. Paleolimnol. 49:513-535.

Catalan J, Pla S, Garcia J, Camarero L, 2009c. Climate and $\mathrm{CO}_{2}$ saturation in an alpine lake throughout the Holocene. Limnol. Oceanogr. 54:2542-2552.

Catalan J, Pla S, Rieradevall M, Felip M, Ventura M, Buchaca T, Camarero L, Brancelj A, Appleby PG, Lami A, Grytnes A, Agusti-Panareda A, Thompson R, 2002a. Lake Redo ecosystem response to an increasing warming in the Pyrenees during the twentieth century. J. Paleolimnol. 28:129-145.

Catalan J, Ventura M, Brancelj A, Granados I, Thies H, Nickus U, Korhola A, Lotter AF, Barbieri A, Stuchlik E, Lien L, Bitusik P, Buchaca T, Camarero L, Goudsmit GH, Kopacek J, Lemcke G, Livingstone DM, Muller B, Rautio M, Sisko M, Sorvari S, Sporka F, Strunecky O, Toro M, 2002b. Seasonal ecosystem variability in remote mountain lakes: implications for detecting climatic signals in sediment records. J. Paleolimnol. 28:25-46.

Catalan J, Ventura M, Vives I, Grimalt JO, 2004. The roles of food and water in the bioaccumulation of organochlorine compounds in high mountain lake fish. Environ. Sci. Technol. 38:4269-4275.

Clague JJ, 2009. Climate change and slope instability, pp 557572. In: K. Sassa and P. canuti (eds.), Landslides - Disaster risk reduction. Springer.

Cuna E, Zawisza E, Caballero M, Ruiz-Fernandez AC, LozanoGarcia S, Alcocer J, 2014. Environmental impacts of Little Ice Age cooling in central Mexico recorded in the sediments of a tropical alpine lake. J. Paleolimnol. 51:1-14.

Curtis CJ, Botev I, Camarero L, Catalan J, Cogalniceanu D, Hughes M, Kernan M, Kopacek J, Korhola A, Psenner R, Rogora M, Stuchlik E, Veronesi M, Wright RF, 2005. Acidification in European mountain lake districts: A regional assessment of critical load exceedance. Aquat. Sci. 67:237-251.

Damme KV, Eggermont H, 2011. The Afromontane Cladocera (Crustacea: Branchiopoda) of the Rwenzori (Uganda-D.R. Congo): taxonomy, ecology and biogeography. Hydrobiologia 676:57-100.

De La Riva I, Reichle S, 2014. Diversity and conservation of the amphibians of Bolivia. Herpetol. Monogr. 28:46-65.
De Mendoza G, Catalan J, 2010. Lake macroinvertebrates and the altitudinal environmental gradient in the Pyrenees. Hydrobiologia 648:51-72.

De Mendoza G, Ventura M, Catalan J, 2015. Environmental factors prevail over dispersal constraints in determining the distribution and assembly of Trichoptera species in mountain lakes. Ecol. Evol. 5:2518-2532.

Degefu F, Herzig A, Jirsa F, Schagerl M, 2014. First limnological records of highly threatened tropical high-mountain crater lakes in Ethiopia. Trop. Conserv. Sci. 7:365-381.

Degefu F, Schagerl M, 2015a. The phytoplankton community of tropical high-mountain crater lake Wonchi, Ethiopia. Hydrobiologia 755:197-208.

Degefu F, Schagerl M, 2015b. Zooplankton abundance, species composition and ecology of tropical high-mountain crater Lake Wonchi, Ethiopia. J. Limnol. 74:324-334.

Demergasso C, Dorador C, Meneses D, Blamey J, Cabrol N, Escudero L, Chong G, 2010. Prokaryotic diversity pattern in high-altitude ecosystems of the Chilean Altiplano. J. Geophys. Res-Biogeo. 115:G00D09.

Dimas-Flores N, Alcocer J, Ciros-Perez J, 2008. The structure of the zooplankton assemblages from two neighboring tropical high mountain lakes. J. Freshw. Ecol. 23:21-31.

Donato-Rondón J, 2010. Phytoplankton of Andean lakes in Northern Southamerica (Colombia). Composition and distribution factors. Koeltz Scientific Books, Oberreifenberg: $188 \mathrm{pp}$.

Eggermont H, Heiri O, Russell J, Vuille M, Audenaert L, Verschuren D, 2010. Paleotemperature reconstruction in tropical Africa using fossil Chironomidae (Insecta: Diptera). J. Paleolimnol. 43:413-435.

Eggermont H, Russell JM, Schettler G, Van Damme K, Bessems I, Verschuren D, 2007. Physical and chemical limnology of alpine lakes and pools in the Rwenzori Mountains (UgandaDR Congo). Hydrobiologia 592:151-173.

Eggermont H, Verschuren D, 2007. Taxonomy and diversity of Afroalpine Chironomidae (Insecta : Diptera) on Mount Kenya and the Rwenzori mountains, East Africa. J. Biogeogr. 34:69-89.

Etter A, Mcalpine C, Possingham HP, 2008. Historical patterns and drivers of landscape change in Colombia since 1500: A regionalized spatial approach. Ann. Assoc. Am. Geogr. 98:2-23.

Felip M, Catalan J, 2000. The relationship between phytoplankton biovolume and chlorophyll in a deep oligotrophic lake: decoupling in their spatial and temporal maxima. J. Plankton Res. 22:91-105.

Fetahi T, Mengistu S, Schagerl M, 2011. Zooplankton community structure and ecology of the tropical-highland Lake Hayq, Ethiopia. Limnologica 41:389-397.

Filonov A, Tereshchenko I, Alcocer J, Monzon C, 2015. Dynamics of internal waves generated by mountain breeze in Alchichica Crater Lake, Mexico. Geofis. Int. 54:21-30.

Finer M, Jenkins CN, 2012. Proliferation of hydroelectric dams in the Andean Amazon and implications for Andes-Amazon connectivity. Plos One 7:e35126.

Flores-Ochoa J, 1979. [Desarrollo de las culturas humanas en las altas montañas tropicales, p. 225-234]. In: M.L. SalgadoLaboriau (ed.), [El medio ambiente del páramo].[Book in Spanish]. Centro de Estudios Avanzados y UNESCO.

Frezzotti M, Orombelli G, 2014. Glaciers and ice sheets: current 
status and trends. Rend. Fis. Acc. Lincei 25:59-70.

Gacia E, Ballesteros E, Camarero L, Delgado O, Palau A, Riera JL, Catalan J, 1994. Macrophytes from lakes in the Eastern Pyrenees - community composition and ordination in relation to environmental factors. Freshwater Biol. 32:73-81.

Gaviria S, 1989. The calanoid fauna (Crustacea, Copepoda), of the Cordillera Oriental of the Colombian Andes. Hydrobiologia 178:113-134.

Guevara SR, Meili M, Rizzo A, Daga R, Arribere M, 2010. Sediment records of highly variable mercury inputs to mountain lakes in Patagonia during the past millennium. Atmos. Chem. Phys. 10:3443-3453.

Gunkel G, 2000. Limnology of an equatorial high mountain lake in Ecuador, Lago San Pablo. Limnologica 30:113-120.

Gunkel G, 2003. Limnology of a high mountain tropical lake, in Ecuador: Characteristics of sediments and rate of sedimentation. Rev. Biol. Trop. 51:381-390.

Halac S, Felip M, Camarero L, Sommaruga-Wograth S, Psenner R, Catalan J, Sommaruga R, 1997. An in situ enclosure experiment to test the solar UVB impact on plankton in a high-altitude mountain lake. I. Lack of effect on phytoplankton species composition and growth. J. Plankton Res. 19:1671-1686.

Heiri O, Brooks SJ, Birks HJB, Lotter AE, 2011. A 274-lake calibration data-set and inference model for chironomid-based summer air temperature reconstruction in Europe. Quaternary Sci. Rev. 30:3445-3456.

Helbling EW, Villafañe V, Buma A, Andrade M, Zaratti F, 2001. DNA damage and photosynthetic inhibition induced by solar ultraviolet radiation in tropical phytoplankton (Lake Titicaca, Bolivia). Eur. J. Phycol. 36:157-166.

Hoorn C, Wesselingh FP, Ter Steege H, Bermudez MA, Mora A, Sevink J, Sanmartín I, Sanchez-Meseguer A, Anderson CL, Figueiredo JP, Jaramillo C, Riff D, Negri FR, Hooghiemstra H, Lundberg J, Stadler T, Särkinen T, Antonelli A, 2010. Amazonia through time: Andean uplift, climate change, landscape evolution, and biodiversity. Science 330:927-931.

Imberger J, 1985. Thermal characteristics of standing waters: an illustration of dynamics processes. Hydrobiologia 125:7-29.

Iturrizaga L, 2014. Glacial and glacially conditioned lake types in the Cordillera Blanca, Peru: A spatiotemporal conceptual approach. Prog. Phys. Geogr. 38:602-636.

Kaser G, Hardy DR, Molg T, Bradley RS, Hyera TM, 2004. Modern glacier retreat on Kilimanjaro as evidence of climate change: Observations and facts. Int. J. Climatol. 24:329-339.

Kernan M, Ventura M, Bitusik P, Brancelj A, Clarke G, Velle G, Raddum GG, Stuchlik E, Catalan J, 2009. Regionalisation of remote European mountain lake ecosystems according to their biota: environmental versus geographical patterns. Freshwater Biol. 54:2470-2493.

Kirch PV, 2005. Archaeology and global change: The Holocene record. Annu. Rev. Env. Resour. 30:409-440.

Knapp RA, 2005. Effects of nonnative fish and habitat characteristics on lentic herpetofauna in Yosemite National Park, USA. Biol. Conserv. 121:265-279.

Knapp RA, Hawkins CP, Ladau J, Mcclory JG, 2005. Fauna of Yosemite National Park lakes has low resistance but high resilience to fish introductions. Ecol. Appl. 15:835-847.

Knapp RA, Matthews KR, 1998. Eradication of nonnative fish by gill netting from a small mountain lake in California. Restor. Ecol. 6:207-213.
Kopáček J, Hejzlar J, Stuchlik E, Fott J, Vesely J, 1998. Reversibility of acidification of mountain lakes after reduction in nitrogen and sulphur emissions in Central Europe. Limnol. Oceanogr. 43:357-361.

Kopáček J, Posch M, 2011. Anthropogenic nitrogen emissions during the Holocene and their possible effects on remote ecosystems. Global Biogeochem. Cy. 25:GB2017.

Körner C, 2007. The use of 'altitude' in ecological research. Trends Ecol. Evol. 22:569-574.

Kotov AA, Sinev AY, Lorena Berrios V, 2010. The Cladocera (Crustacea: Branchiopoda) of six high altitude water bodies in the North Chilean Andes, with discussion of Andean endemism. Zootaxa 2430:1-66.

Leavitt PR, Fritz SC, Anderson NJ, Baker PA, Blenckner T, Bunting L, Catalan J, Conley DJ, Hobbs WO, Jeppesen E, Korhola A, Mcgowan S, Ruehland K, Rusak JA, Simpson GL, Solovieva N, Werne J, 2009. Paleolimnological evidence of the effects on lakes of energy and mass transfer from climate and humans. Limnol. Oceanogr. 54:23302348 .

Lewis WM, 1996. Tropical lakes: How latitude makes a difference, p. 43-64. In: F. Schiemer and K.T. Boland (eds.), Perspectives in tropical limnology. SPB Academic Publishing.

Lewis WM Jr, 2010. Biogeochemistry of tropical lakes. Verh. Internat. Verein. Limnol. 30:1595-1603.

Lewis WM Jr, 2011. Global primary production of lakes: 19th Baldi Memorial Lecture. Inland Waters 1:1-28.

Löffler H, 1962. The limnology of tropical high-mountain lakes. Int. Ver. Theor. Angew. Limnol. Verh. 15:176-193.

Löffler H, 1983. Aspects of the history and evolution of Alpine lakes in Austria. Hydrobiologia 100:143-152.

Lopez-Moreno JI, Fontaneda S, Bazo J, Revuelto J, AzorinMolina C, Valero-Garces B, Moran-Tejeda E, Vicente-Serrano SM, Zubieta R, Alejo-Cochachin J, 2014. Recent glacier retreat and climate trends in Cordillera Huaytapallana, Peru. Glob. Planet. Change 112:1-11.

Llorens-Mares T, Auguet JC, Casamayor EO, 2012. Winter to spring changes in the slush bacterial community composition of a high-mountain lake (Lake Redon, Pyrenees). Environ. Microbiol. Rep. 4:50-56.

Macek M, Callieri C, Simek K, Vazquez AL, 2006. Seasonal dynamics, composition and feeding patterns of ciliate assemblages in oligotrophic lakes covering a wide $\mathrm{pH}$ range. Arch. Hydrobiol. 166:261-287.

Marlon JR, Bartlein PJ, Daniau AL, Harrison SP, Maezumi SY, Power MJ, Tinner W, Vanniere B, 2013. Global biomass burning: a synthesis and review of Holocene paleofire records and their controls. Quaternary Sci. Rev. 65:5-25.

Matson PA, Mcdowell WH, Townsend AR, Vitousek PM, 1999. The globalization of $\mathrm{N}$ deposition: ecosystem consequences in tropical environments. Biogeochemistry 46:67-83.

Mcglynn G, Mackay AW, Rose NL, Taylor RG, Leng MJ, Engstrom DR, 2010. Palaeolimnological evidence of environmental change over the last 400 years in the Rwenzori Mountains of Uganda. Hydrobiologia 648:109-122.

Meire RO, Lee SC, Yao Y, Targino AC, Torres JPM, Harner T, 2012. Seasonal and altitudinal variations of legacy and current-use pesticides in the Brazilian tropical and subtropical mountains. Atmos. Environ. 59:108-116.

Michelutti N, Cooke C, Hobbs W, Smol J, 2015. Climate-driven 
changes in lakes from the Peruvian Andes. J. Paleolimnol. 54:153-160.

Miró A, Ventura M, 2013. Historical use, fishing management and lake characteristics explain the presence of non-native trout in Pyrenean lakes: Implications for conservation Biol. Conserv. 167:17-24.

Miró A, Ventura M, 2015. Evidence of exotic trout mediated minnow invasion in Pyrenean high mountain lakes. Biol. Invasions 17:791-803.

Mountain Research Initiative EDW Working Group, 2015. Elevation-dependent warming in mountain regions of the world. Nature Clim. Change 5:424-430.

Niemann H, Behling H, 2009. Late Pleistocene and Holocene environmental change inferred from the Cocha Caranga sediment and soil records in the southeastern Ecuadorian Andes. Palaeogeogr. Palaeoclimatol. Palaeoecol. 276:1-14.

Niemann H, Haberzettl T, Behling H, 2009. Holocene climate variability and vegetation dynamics inferred from the (11700 cal. yr BP) Laguna Rabadilla de Vaca sediment record, southeastern Ecuadorian Andes. Holocene 19:307-316.

Nunez-Cardona MT, Donato Rondon JC, Reynolds CS, Mas J, 2008. A purple sulfur bacterium from a high-altitude lake in the Colombian Andes. J. Biol. Res. Thesssalon. 9:17-24.

Paulsen J, Korner C, 2014. A climate-based model to predict potential treeline position around the globe. Alpine Botany 124:1-12.

Pechlaner R, 1971. Factors that control the production rate and biomass of phytoplankton in high mountain lakes. Mitt. Internat. Verein. Limnol. 19:125-145.

Pelachs A, Julia R, Perez-Obiol R, Manuel Soriano J, Bal M-C, Cunill R, Catalan J, 2011. Potential influence of Bond events on mid-Holocene climate and vegetation in southern Pyrenees as assessed from Burg lake LOI and pollen records. Holocene 21:95-104.

Perdomo L, 1989. [Manual de arqueología colombiana]. [Book in Spanish]. Carlos Valencia.

Peters T, Drobnik T, Meyer H, Rankl M, Richter M, Rollenbeck R, Thies B, Bendix J. 2013. Environmental Changes Affecting the Andes of Ecuador, p. 19-29. In: J. Bendix, E. Beck, A. Bräuning, F. Makeschin, R. Mosandl, S. Scheu and W. Wilcke (eds.), Ecosystem services, biodiversity and environmental change in a tropical mountain ecosystem of South Ecuador. Springer.

Pinilla-A GA, Donato-Rondón JC, Rivera-R CA, 2006. Photosynthetic efficiency of phytoplankton in a tropical mountain lake. Caldasia 28:57-66.

Pla-Rabes S, Catalan J, 2011. Deciphering chrysophyte responses to climate seasonality. J. Paleolimnol. 46:139-150.

Polissar PJ, Abbott MB, Wolfe AP, Vuille M, Bezada M, 2013. Synchronous interhemispheric Holocene climate trends in the tropical Andes. P. Natl. Acad. Sci. USA 110:14551-14556.

Psenner R, Catalan J, 1994. Chemical composition of lakes in crystalline basins: a combination of atmospheric deposition geologic backgrounds, biological activity and human action, p. 81-97. In: R. Margalef (ed.), Limnology now. A paradigm of planetary problems. Elsevier.

Psenner R, Schmidt R, 1992. Climate-driven $\mathrm{pH}$ control of remote Alpine lakes and effects of acid deposition. Nature 356:781-783.

Pulido C, Riera JL, Ballesteros E, Chappuis E, Gacia E, 2015.
Predicting aquatic macrophyte occurrence in soft-water oligotrophic lakes (Pyrenees mountain range). J. Limnol. 74: 143-154.

Ramírez J, 1975. [La laguna de Guatavita].[Article in Spanish]. Bol. Soc. Geogr. Colomb. 29:45-60.

Reche I, Ortega-Retuerta E, Romera O, Pulido-Villena E, Morales-Baquero R, Casamayor EO, 2009. Effect of Saharan dust inputs on bacterial activity and community composition in Mediterranean lakes and reservoirs. Limnol. Oceanogr. 54:869-879.

Rietti-Shati M, Yam R, Karlen W, Shemesh A, 2000. Stable isotope composition of tropical high-altitude fresh-waters on Mt. Kenya, Equatorial East Africa. Chem. Geol. 166:341-350.

Rivera C, Solano D, Zapata A, Donato J, 2005. Phytoplankton diversity in a tropical high mountain lake. Int. Ver. Theor. Angew. 29:418-421.

Rivera Rondon CA, Zapata AM, Donaton Rondón JC, 2010. Estudio morfométrico del lago Guatavita (Colombia). Acta Biol. Colomb. 15:131-144.

Rodbell DT, Smith JA, Mark BG, 2009. Glaciation in the Andes during the Lateglacial and Holocene. Quaternary Sci. Rev. 28:2165-2212.

Roepke A, Stobbe A, Oeggl K, Kalis AJ, Tinner W, 2011. LateHolocene land-use history and environmental changes at the high altitudes of St Antonien (Switzerland, Northern Alps): combined evidence from pollen, soil and tree-ring analyses. Holocene 21:485-498.

Rühland K, Paterson A, Smol J, 2015. Lake diatom responses to warming: reviewing the evidence. J. Paleolimnol. 54:1-35.

Russell J, Eggermont H, Taylor R, Verschuren D, 2009. Paleolimnological records of recent glacier recession in the Rwenzori Mountains, Uganda-D.R. Congo. J. Paleolimnol. 41:253-271.

Sarmiento FO, 2000. Breaking mountain paradigms: Ecological effects on human impacts in man-aged Tropandean landscapes. Ambio 29:423-431.

Schmidt R, Wunsam S, Brosch U, Fott J, Lami A, Loffler H, Marchetto A, Muller HW, Prazakova M, Schwaighofer B, 1998. Late and post glacial history of meromictic Langsee (Austria), in respect to climate change and anthropogenic impact. Aquat. Sci. 60:56-88.

Schueler L, Hemp A, Zech W, Behling H, 2012. Vegetation, climate and fire-dynamics in East Africa inferred from the Maundi crater pollen record from Mt Kilimanjaro during the last glacial-interglacial cycle. Quaternary Sci. Rev. 39:1-13.

Shunthirasingham C, Gouin T, Lei YD, Ruepert C, Castillo LE, Wania F, 2011. Current-use pesticide transport to Costa Rica's high-altitude tropical cloud forest. Environ. Toxicol. Chem. 30:2709-2717.

Skrzypek G, Engel Z, Chuman T, Sefrna L, 2011. Distichia peat - A new stable isotope paleoclimate proxy for the Andes. Earth Planet. Sc. Lett. 307:298-308.

Solomina ON, Bradley RS, Hodgson DA, Ivy-Ochs S, Jomelli V, Mackintosh AN, Nesje A, Owen LA, Wanner H, Wiles GC, Young NE, 2015. Holocene glacier fluctuations. Quaternary Sci. Rev. 111:9-34.

Sommaruga R, 2001. The role of solar UV radiation in the ecology of alpine lakes. J. Photochem. Photobiol. B-Biol. 62:35-42.

Straskrabova V, Bertoni R, Blazo M, Callieri C, Forsstrom L, Fott J, Kernan M, Macek M, Stuchlik E, Tolotti M. 2009. 
Structure of pelagic microbial assemblages in European mountain lakes during ice-free season, p. 19-53. In: J. Catalan, C.J. Curtis and M. Kernan (eds.), Patterns and factors of biota distribution in remote European mountain lakes. Advances in Limnology. Schweizerbart Science Publ.

Taylor RG, Mileham L, Tindimugaya C, Mwebembezi L, 2009. Recent glacial recession and its impact on alpine riverflow in the Rwenzori Mountains of Uganda. J. Afr. Earth Sci. 55:205-213.

Tinner W, Conedera M, Ammann B, Lotter AF, 2005. Fire ecology north and south of the Alps since the last ice age. Holocene 15:1214-1226.

Triado-Margarit X, Casamayor EO, 2012. Genetic diversity of planktonic eukaryotes in high mountain lakes (Central Pyrenees, Spain). Environ. Microbiol. 14:2445-2456.

Ventura M, Petrusek A, Miro A, Hamrova E, Bunay D, De Meester L, Mergeay J, 2014. Local and regional founder effects in lake zooplankton persist after thousands of years despite high dispersal potential. Mol. Ecol. 23:1014-1027.

Vila-Costa M, Bartrons M, Catalan J, Casamayor E, 2014. Nitrogen-Cycling Genes in Epilithic Biofilms of Oligotrophic High-Altitude Lakes (Central Pyrenees, Spain). Microb. Ecol. 68:60-69.
Vilaclara G, Cuna E, Zeeb B, 2005. Subfossil chrysophyte cyst morphotypes from two tropical, high-mountain lakes in Nevado de Toluca volcano, Central Mexico. Nova Hedwigia 128:309-335.

Vinebrooke RD, Leavitt PR, 1996. Efffects of ultraviolet radiation on periphyton in an alpine lake. Limnol. Oceanogr. 41:1035-1040.

Wann JK, Chen CTA, Wang BJ, 1997. A Seasonally Anoxic Mountain Lake with an Active Fe Cycle in Tropical Taiwan. Aquat. Geochem. 3:21-42.

Wolfe AP, Van Gorp AC, Baron JS, 2003. Recent ecological and biogeochemical changes in alpine lakes of Rocky Mountain National Park (Colorado, USA): a response to anthropogenic nitrogen deposition. Geobiology 1:153-168.

Wunder S, 1996. Deforestation and the uses of wood in the Ecuadorian Andes. Mt. Res. Dev. 16:367-381.

Yang H, Engstrom DR, Rose NL, 2010. Recent Changes in Atmospheric Mercury Deposition Recorded in the Sediments of Remote Equatorial Lakes in the Rwenzori Mountains, Uganda. Environ. Sci. Technol. 44:6570-6575.

Zapata-Anzola AM, Rivera-Rondon CA, Donato-Rondón JC, 2006. Dynamics of photosynthetic pigments in an Andean Lake in Colombia. Lakes Reserv. Res. Manag. 11:29-38. 